\title{
ARTICLE
}

Chronic myelogenous leukemia

\section{High-risk additional chromosomal abnormalities at low blast counts herald death by CML}

\author{
Rüdiger Hehlmann ${ }^{1,2} \cdot$ Astghik Voskanyan $^{2} \cdot$ Michael Lauseker $^{3} \cdot$ Markus Pfirrmann $^{3} \cdot$ Lida Kalmanti $^{2}$. \\ Sebastien Rinaldetti ${ }^{2} \cdot$ Katharina Kohlbrenner $^{2}$ - Claudia Haferlach ${ }^{4} \cdot$ Brigitte Schlegelberger $^{5}$ - Alice Fabarius ${ }^{2}$. \\ Wolfgang Seifarth ${ }^{2} \cdot$ Birgit Spieß ${ }^{2} \cdot$ Patrick Wuchter $^{6} \cdot$ Stefan Krause $\mathbb{D}^{7} \cdot$ Hans-Jochem Kolb ${ }^{8} \cdot$ Andreas Neubauer $^{9}$. \\ Dieter K. Hossfeld ${ }^{10}$. Christoph Nerl ${ }^{11}$ - Alois Gratwohl ${ }^{12}$. Gabriela M. Baerlocher ${ }^{13}$. Andreas Burchert $^{9}$. \\ Tim H. Brümmendorf ${ }^{14} \cdot$ Jörg Hasford ${ }^{3}$. Andreas Hochhaus ${ }^{15}$. Susanne Saußele ${ }^{2}$. Michele Baccarani ${ }^{16} \cdot$ for the $^{2}$ \\ SAKK and the German CML Study Group
}

Received: 27 February 2020 / Revised: 2 March 2020 / Accepted: 30 March 2020

(c) The Author(s) 2020. This article is published with open access

\begin{abstract}
Blast crisis is one of the remaining challenges in chronic myeloid leukemia (CML). Whether additional chromosomal abnormalities (ACAs) enable an earlier recognition of imminent blastic proliferation and a timelier change of treatment is unknown. One thousand five hundred and ten imatinib-treated patients with Philadelphia-chromosome-positive $(\mathrm{Ph}+) \mathrm{CML}$ randomized in CML-study IV were analyzed for ACA/Ph + and blast increase. By impact on survival, ACAs were grouped into high risk $(+8,+\mathrm{Ph}, \mathrm{i}(17 \mathrm{q}),+17,+19,+21,3 \mathrm{q} 26.2,11 \mathrm{q} 23,-7 / 7 \mathrm{q}$ abnormalities; complex) and low risk (all other). The presence of high- and low-risk ACAs was linked to six cohorts with different blast levels $(1 \%, 5 \%, 10 \%, 15 \%, 20 \%$, and $30 \%)$ in a Cox model. One hundred and twenty-three patients displayed ACA/Ph+ $(8.1 \%), 91$ were high risk. At low blast levels (1-15\%), high-risk ACA showed an increased hazard to die compared to no ACA (ratios: 3.65 in blood; 6.12 in marrow) in contrast to low-risk ACA. No effect was observed at blast levels of 20-30\%. Sixty-three patients with high-risk ACA $(69 \%)$ died $(n=37)$ or were alive after progression or progression-related transplantation $(n=26)$. High-risk ACA at low blast counts identify end-phase CML earlier than current diagnostic systems. Mortality was lower with earlier treatment. Cytogenetic monitoring is indicated when signs of progression surface or response to therapy is unsatisfactory.
\end{abstract}

Members of the SAKK and the German CML Study Group are listed below Acknowledgements.

Rüdiger Hehlmann

hehlmann.eln@gmail.com

ELN Foundation, Weinheim, Germany

2 III. Medizinische Klinik, Medizinische Fakultät Mannheim, Universität Heidelberg, Mannheim, Germany

3 IBE Universität München, München, Germany

4 MLL, München, Germany

5 Institut für Humangenetik, MHH, Hannover, Germany

6 Institut für Transfusionsmedizin und Immunologie, Medizinische Fakultät Mannheim, Universität Heidelberg und DRKBlutspendedienst, Mannheim, Germany

7 Medizinische Klinik 5, Universitätsklinikum, Erlangen, Germany

\section{Introduction}

Blast crisis (BC) of Philadelphia-chromosome-positive $(\mathrm{Ph}+)$ and/or BCR-ABL1-positive chronic myeloid

8 Medizinische Klinik III, Universitätsklinikum Großhadern, München, Germany

9 Klinik für Innere Medizin, Universitätsklinikum, Marburg, Germany

10 2. Medizinische Klinik, Universitätsklinikum Eppendorf, Hamburg, Germany

11 Klinikum Schwabing, München, Germany

12 Universitätsspital, Basel, Switzerland

13 Inselspital, Bern, Switzerland

14 Uniklinik RWTH, Aachen, Germany

15 Klinik für Innere Medizin II, Universitätsklinikum, Jena, Germany

16 Department of Hematology-Oncology, Policlinico S.OrsolaMalpighi, University of Bologna, Bologna, Italy 
leukemia (CML) is one of the remaining challenges in the management of the disease. Cytogenetic abnormalities and blast increase represent the most consistent indicators of progression to end-phase CML [1-7]. End-phase CML comprises early progression with emerging high-risk ACA and late progression with failing hematopoiesis and blast cell proliferation. BC represents the end stage of this evolution. Not all patients dying of CML reach the blast levels defining BC (20\% or $30 \%$ blasts in blood or marrow) [8-11]. Once $\mathrm{BC}$ has occurred, treatment results are poor. Early allogeneic stem cell transplantation (SCT) might improve prognosis $[12,13]$. Whether cytogenetic aberrations allow a timelier change of treatment with better outcome is unknown.

Additional chromosomal abnormalities (ACAs) are thought to result from BCR-ABL1-induced genetic instability and may be causative factors of disease progression $[14,15]$. The most frequent ACAs found in BC $(+8$, a second $\mathrm{Ph}$-chromosome $(+\mathrm{Ph})$, an isochromosome of the long arm of chromosome 17, i.e., i[17q], and +19 ) were termed major route by Mitelman et al. [1-2]. Majorroute ACAs have been associated with shorter survival, if they were detected at diagnosis [16] or if they emerged in the course of disease [17]. A poor prognosis was also observed with 3q26.2 and 11q23 rearrangements and with $-7 / 7 \mathrm{q}-[18,19]$, whereas +8 and $+\mathrm{Ph}$ as single aberrations, but not in combination, were not equally associated with poor prognosis [20]. Wang et al. [17] proposed a risk stratification of the six most frequent ACAs into two groups with distinct prognoses $(+8,+\mathrm{Ph},-\mathrm{Y}$ with good prognoses and $\mathrm{i}[17 \mathrm{q}],-7 / 7 \mathrm{q}-, 3 \mathrm{q} 26.2$ rearrangements with poor prognoses). Using the same cohort of patients, a risk stratification into three groups was proposed [21] based on BC risk associated with each ACA (high risk: $3 \mathrm{q} 26.2 ;-7 / 7 \mathrm{q}-$; $\mathrm{i}[17 \mathrm{q}]$; complex karyotypes with high-risk ACA.
Intermediate $1:+8 ;+\mathrm{Ph}$; other single ACA. Intermediate 2 : other complex ACA).

Since the prognosis with single changes $(+8,+\mathrm{Ph})$ is controversial, we decided to include these in our evaluation, as well as +21 and +17 , which were designated as major route later on [1]. Other ACAs were not so clearly associated with shorter survival. This led to their tentative designation as low-risk ACA.

More recently, clonal chromosomal aberrations (CCAs) found in $\mathrm{Ph}$-negative cells $(\mathrm{CCA} / \mathrm{Ph}-)$ were reported to also have a negative impact on survival $[22,23]$.

We here made use of the data of 1551 imatinib-treated chronic phase (CP) patients recruited to CML-study IV, a randomized study comparing imatinib $400 \mathrm{mg}$ with imatinib $800 \mathrm{mg}$ and combinations of imatinib with interferon, simultaneously or sequentially, or low-dose cytarabine [24]. Our aim was to analyze if defined ACA at low blast levels allow an earlier diagnosis of end-phase CML and a timelier change of treatment than current blast thresholds.

\section{Patients and methods}

\section{Patients}

Patient data were derived from the randomized CML-study IV (recruitment 2002-2012) with initial or predominant imatinib treatment [24]. Documentation was done at 3-6month intervals as previously reported [24]. Risk assignment followed the ELTS (EUTOS Long-Term Survival) score [25]. BC was defined by $30 \%$ blasts in blood or marrow. Patient numbers and flow are depicted in the flow chart (Fig. 1a-c).
Fig. 1 Flow chart. a Patients with ACA, b patients with $\mathrm{BC}$, and $\mathbf{c}$ transplanted patients with high-risk ACA. BC blast crisis, AP accelerated phase, SCT stem cell transplantation.

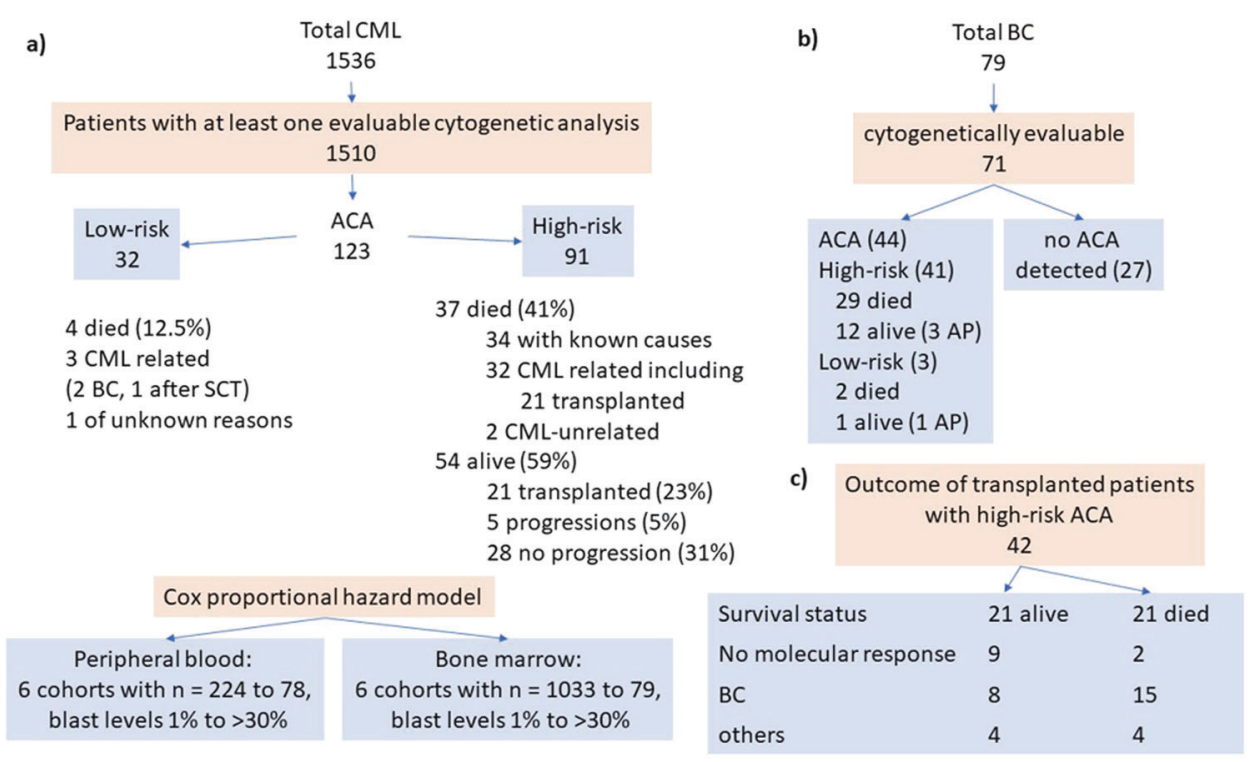




\section{Cytogenetics}

By protocol, cytogenetic analysis was requested every 3-6 months during the early disease phases and every 12 months thereafter, if stable molecular remission (major molecular remission or better, BCR-ABL $1<0.1 \%$ on the International Scale, IS) was achieved. In stable molecular remission, intervals between cytogenetic analyses were frequently longer due to patients' and/or doctors' requests. A median of four analyses per patient were documented. Cytogenetic analyses were done as described and results were reported according to the international nomenclature (ISCN 2016) [16]. ACAs were evaluated if they were clonal according to the ISCN. Complex karyotypes were defined as three or more concurrent aberrations. High-risk ACAs were defined as the major route $\mathrm{ACA}+8,+\mathrm{Ph}, \mathrm{i}[17 \mathrm{q}],+19,+21,+17$ (the ACA most frequently observed in $\mathrm{BC}$ ) [1], the minor route ACA $3 q 26.2,11 q 23,-7 / 7 q-$ (less frequently observed, but negative impact on prognosis) [17, 19, 18], and complex karyotypes. Variant translocations and $-\mathrm{Y}$ were not considered, as they had no impact on prognosis in our and other studies [16, 26].

$\mathrm{CAA} / \mathrm{Ph}$ - have not been an objective of this study.

\section{Molecular genetics}

Molecular analyses followed the IS methodology and nomenclature [27-30].

\section{Statistics}

For survival analyses, patients were followed up at the start of the diagnosis, at the time of the occurrence of an ACA, or at the time of a blast increase. Patients were censored at the date of last follow-up. Mortality after the advent of blast increases was assessed by Cox models starting at the time of a blast increase. Here the presence of ACA was considered as a time-dependent covariate. $P$ values $<5 \%$ were considered significant. Due to the explorative character of this work, no adjustment of $p$ values was done and all $p$ values have to be interpreted descriptively. All analyses were performed with SAS 9.3 or R 3.5.1.

\section{Results}

\section{Identification of ACA}

One thousand five hundred and thirty-six patients with $\mathrm{Ph}+$ CP-CML were analyzed for blast increase and ACA, 1510 patients were cytogenetically evaluable. Patients'
Table 1 Patient characteristics.

\begin{tabular}{|c|c|}
\hline Patients (cytogenetically evaluable), $n$ & $1536(1510)$ \\
\hline Gender $(\%)$, male & 60.2 \\
\hline Age at diagnosis of CML (years), median (range) & $53(16-88)$ \\
\hline $\mathrm{Hb}(\mathrm{g} / \mathrm{dl})$, median (range) & $12.3(4.7-19.1)$ \\
\hline Platelets $\left(\times 10^{12} / \mu \mathrm{l}\right)$, median (range) & $375(34-3020)$ \\
\hline Patients with palpable splenomegaly & $55.7 \%$ \\
\hline ELTS-score (\% low/intermediate/high) & $57 / 30 / 13$ \\
\hline $\begin{array}{l}\text { WBC count at diagnosis }\left(\times 10^{9} / 1\right) \text { (median, range) } \\
\text { with differential }\end{array}$ & $76(2.6-630)$ \\
\hline Blasts $(\%)$ & $1(0-30)$ \\
\hline Promyelocytes $(\%)$ & $2(0-34)$ \\
\hline Basophils $(\%)$ & $3(0-66)$ \\
\hline Median observation time (years) & 8.6 \\
\hline 10-Year survival & $83 \%$ \\
\hline Patients with ACA, high risk at diagnosis $(n)$ & 25 \\
\hline $\begin{array}{l}\text { Patients with ACA, high risk in the course of } \\
\text { disease }(n)\end{array}$ & 66 \\
\hline High-risk ACA total $(n)$ & $91(6 \%)$ \\
\hline Patients with other-/low-risk ACA at diagnosis $(n)$ & 19 \\
\hline $\begin{array}{l}\text { Patients with other-/low-risk ACA in the course of } \\
\text { disease }(n)\end{array}$ & 13 \\
\hline Low-risk ACA, total $(n)$ & $32(2.1 \%)$ \\
\hline ACA total $(n)$ & $123(8.1 \%)$ \\
\hline $\begin{array}{l}\text { Patients with anemia }(\mathrm{Hb}<10) \text { at first appearance } \\
\text { of ACA }(\%)\end{array}$ & $26.7^{\mathrm{a}}$ \\
\hline $\begin{array}{l}\text { Patients with thrombocytopenia (platelets }<75 \times \\
\left.10^{9} / 1\right) \text { at first appearance of ACA }(\%)\end{array}$ & $17.8^{\mathrm{a}}$ \\
\hline $\begin{array}{l}\text { Patients with neutropenia (neutrophils }<1.5 \times 10^{6} / \text { l) } \\
\text { at first appearance of ACA }(\%)\end{array}$ & $15.5^{\mathrm{a}}$ \\
\hline $\begin{array}{l}\text { Patients with palpable splenomegaly (defined as } \\
\text { spleen in } \mathrm{cm} \text { below costal margin }>0 \text { ) at first } \\
\text { appearance of ACA }(\%)\end{array}$ & $39.2^{\mathrm{a}}$ \\
\hline Basophils at the time of ACA (\%) (median, range) & $1(0-15)^{\mathrm{a}}$ \\
\hline Age at diagnosis of ACA (years) (median, range) & $52(18-89)$ \\
\hline $\begin{array}{l}\text { Age at diagnosis of high-risk ACA (years) } \\
\text { (median, range) }\end{array}$ & $52(23-89)$ \\
\hline $\begin{array}{l}\text { Median interval diagnosis-ACA (years) (median, } \\
\text { range) }\end{array}$ & n.r. $(0-11.1)^{\mathrm{b}}$ \\
\hline
\end{tabular}

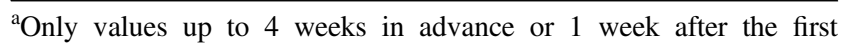
appearance of ACAs were counted $(n \geq 74)$.

${ }^{\mathrm{b}}$ Maximum number $=$ emergence of last ACA, n.r. not reported.

characteristics are shown in Table 1. Median observation time was 8.6 years.

One hundred and twenty-three patients $(8.1 \%)$ displayed $\mathrm{ACA}$ in $\mathrm{Ph}+$ metaphases (Appendix A1). Ninety one (6\%) were high-risk ACAs $(+8,+\mathrm{Ph}, \mathrm{i}[17 \mathrm{q}],+17,+19,+21$, $11 \mathrm{q} 23$ and $3 \mathrm{q} 26.2$ rearrangements, $-7 / 7 \mathrm{q}$ abnormalities, complex karyotypes) and $32(2.1 \%)$ were low-risk ACAs (all other). Of the 91 high-risk ACAs, 25 (1.7\%) were detected at baseline and $66(4.4 \%)$ emerged in the course of 
Table 2 Frequency of ACA.

\begin{tabular}{|c|c|c|c|}
\hline Karyotypes & Single ACA & $\begin{array}{l}\text { In combination with } \\
\text { other ACA }\end{array}$ & Tota \\
\hline \multicolumn{4}{|c|}{ High-risk ACA $(n=91)^{\mathrm{a}}$} \\
\hline+8 & 19 & 19 & 38 \\
\hline At diagnosis & 6 & 10 & 16 \\
\hline $\begin{array}{l}\text { In the course of } \\
\text { disease }\end{array}$ & 13 & 9 & 22 \\
\hline$+\mathrm{Ph}$ & 18 & 17 & 35 \\
\hline At diagnosis & 7 & 6 & 13 \\
\hline $\begin{array}{l}\text { In the course of } \\
\text { disease }\end{array}$ & 11 & 11 & 22 \\
\hline+19 & 0 & 11 & 11 \\
\hline At diagnosis & 0 & 4 & 4 \\
\hline $\begin{array}{l}\text { In the course of } \\
\text { disease }\end{array}$ & 0 & 7 & 7 \\
\hline$+17 / \mathrm{i}(17 \mathrm{q})$ & 3 & 5 & 8 \\
\hline At diagnosis & 1 & 3 & 4 \\
\hline $\begin{array}{l}\text { In the course of } \\
\text { disease }\end{array}$ & 2 & 2 & 4 \\
\hline $3 q 26.2$ & 10 & 2 & 12 \\
\hline At diagnosis & 1 & 0 & 1 \\
\hline $\begin{array}{l}\text { In the course of } \\
\text { disease }\end{array}$ & 9 & 2 & 9 \\
\hline$-7 / 7 \mathrm{q}$ abnormalities & 5 & 4 & 9 \\
\hline At diagnosis & 1 & 0 & 1 \\
\hline $\begin{array}{l}\text { In the course of } \\
\text { disease }\end{array}$ & 4 & 4 & 8 \\
\hline+21 & 2 & 3 & 5 \\
\hline At diagnosis & 1 & 1 & 2 \\
\hline $\begin{array}{l}\text { In the course of } \\
\text { disease }\end{array}$ & 1 & 2 & 3 \\
\hline $11 \mathrm{q} 23$ & 1 & 0 & 1 \\
\hline At diagnosis & 0 & 0 & 0 \\
\hline $\begin{array}{l}\text { In the course of } \\
\text { disease }\end{array}$ & 1 & 0 & 1 \\
\hline Complex karyotypes & & 25 & 25 \\
\hline At diagnosis & & 11 & 11 \\
\hline $\begin{array}{l}\text { In the course of } \\
\text { disease }\end{array}$ & & 14 & 14 \\
\hline Low-risk ACA & 32 & 32 & \\
\hline At diagnosis & 19 & 19 & \\
\hline $\begin{array}{l}\text { In the course of } \\
\text { disease }\end{array}$ & 13 & 13 & \\
\hline
\end{tabular}

${ }^{\mathrm{a}}$ Multiple listings possible.

disease $0.5-133$ months after diagnosis. The median time to detection of high-risk ACAs was 17 months. Of the 32 lowrisk ACAs, 19 (1.3\%) were detected at diagnosis and 13 $(0.9 \%)$ emerged in the course of disease.

Frequencies of ACA are shown in Table 2 grouped according to type (risk level, single, or in combination) and time of emergence (at diagnosis or in the course of disease).

\section{Impact of ACA on survival}

Figure 2a-d shows the impact of high- and low-risk ACAs on survival from occurrence of ACA at diagnosis or in the course of disease. Observations were synchronized for the time of emergence of ACA, and ACA detected at diagnosis and emerging in the course of disease were analyzed together. All high-risk ACAs show a negative impact on survival compared to low-risk ACAs, which serve as control. An exception is +8 as a single aberration, which carries a prognosis in between high- and low-risk ACAs (Fig. 2a). Impact of $+\mathrm{Ph}$ on survival was equally poor whether it occurred alone or in combination with other abnormalities (Fig. 2b). Chromosome 3, 7, 17, 19, and 21 aberrations were grouped together, as they were rare (Fig. 2d). Individual analyses of these aberrations are shown in Fig. 2e-i. Four-year survival probability after occurrence of high-risk ACA, except +8 alone, was $52.2 \%$ (95\% confidence interval (CI): 41-66), after occurrence of +8 alone $77 \%$ (95\% CI: 60-100), and after occurrence of lowrisk ACA $87 \%$ (95\% CI: 75-100).

The treatment strategy after emergence of ACA including allogeneic SCT did not differ according to the type of ACA, but patients with high-risk ACA were transplanted more frequently. 42 of the 138 transplantations in CMLstudy IV $(30 \%)$ were performed in the $6 \%$ of patients with high-risk ACA (Flow chart, Fig. 1c). Two-year survival of 26 patients transplanted in $\mathrm{BC}$ or accelerated phase (AP) was $46 \%$ (95\% CI: $26-63 \%$ ) and of 13 patients transplanted in CP 77\% (95\% CI: 44-92\%; log-rank test: $p=0.09$; phase unknown for 3 of 42 patients).

\section{Correlation of ACA with BC}

79 patients developed $\mathrm{BC}$ during the observation time. Of the $79 \mathrm{BC}$ patients, 71 were cytogenetically evaluable. 44 BC patients had ACA (61\%), in 27 patients no ACAs were reported. Of the $44 \mathrm{BC}$ patients with ACA, 41 (93\%) had high-risk and 3 low-risk ACA (Flow chart, Fig. 1b).

\section{Correlation of ACA with blast increase}

The close correlation of high-risk ACA with $\mathrm{BC}$ and the unfavorable prognosis of patients with high-risk ACA led us to ask if high-risk ACA can anticipate the diagnosis of end-phase CML. We therefore assigned patients, in whom a blast increase was observed in peripheral blood or marrow (at any time), to 6 different blast thresholds (1\%, 5\%, 10\%, $15 \%, 20 \%$, and $30 \%)$. In each of these cohorts high- and low-risk ACAs were considered as time-dependent variables. The number of patients ranged from 224 to 78 in the six cohorts with blast increases of $1 \%$ to $>30 \%$ in the peripheral blood, and from 1033 to 79 in the six cohorts with 

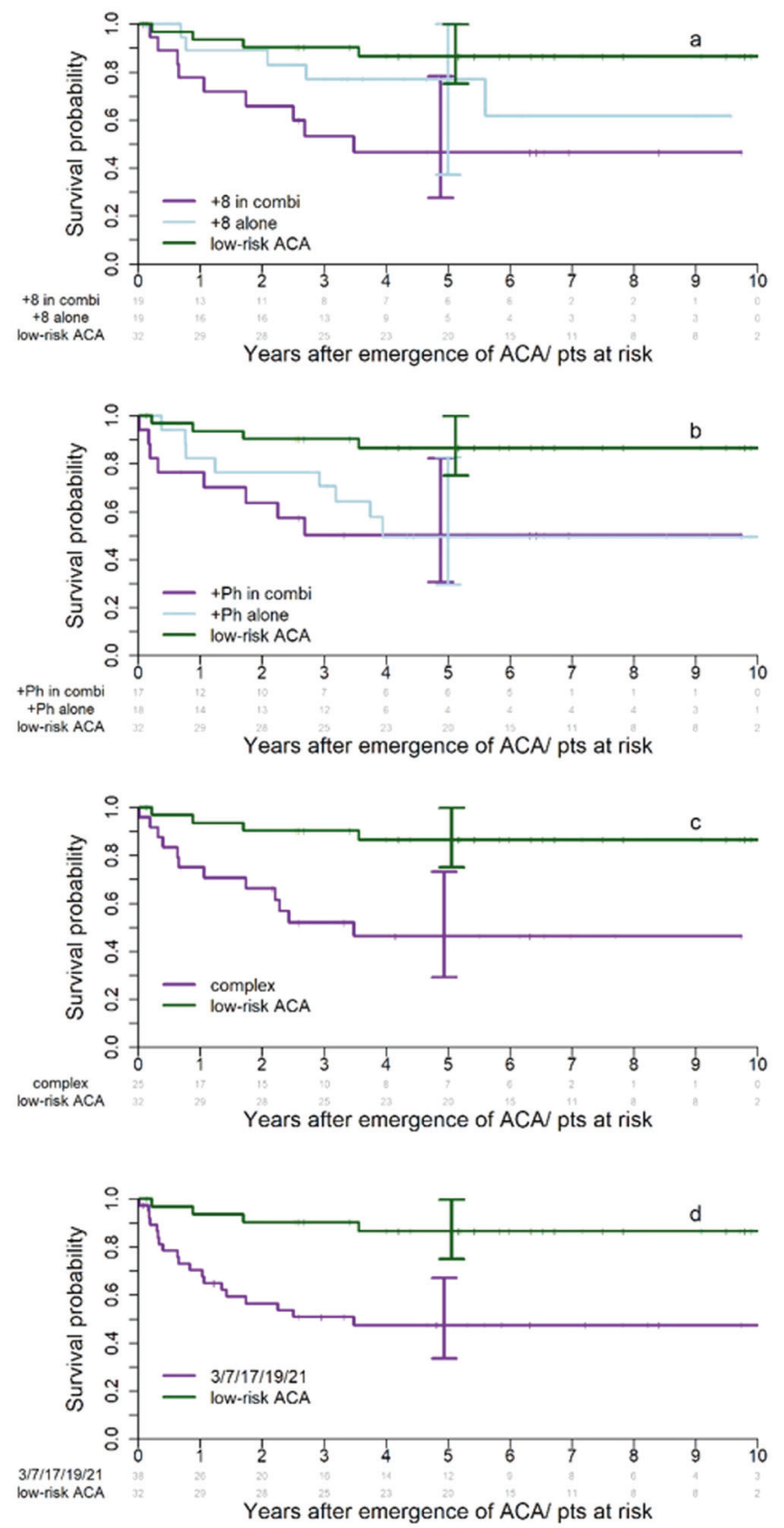

Fig. 2 Impact of high- vs. low-risk ACA on survival. The left-side panel shows the impact of $+8(\mathbf{a}),+\mathrm{Ph}(\mathbf{b})$, complex ACA (c), and of chromosome $3,7,17,19$, and 21 aberrations combined (d) on survival in patients with primary imatinib treatment after the emergence of

blast levels of $1 \%$ to $>30 \%$ in the marrow (Table 3). Naturally, the sets of patients who developed higher blast increases later on were subsets of the sets with lower blast increases.

In the corresponding Cox proportional hazards models (Table 3, Fig. 3), we found an increased hazard to die in the presence of high-risk ACA compared to no ACA with hazard ratios of up to 3.65 (95\% CI: 2.32-5.75) in the blood (Fig. 3a) and 6.12 (95\% CI: 4.1-9.2) in the marrow
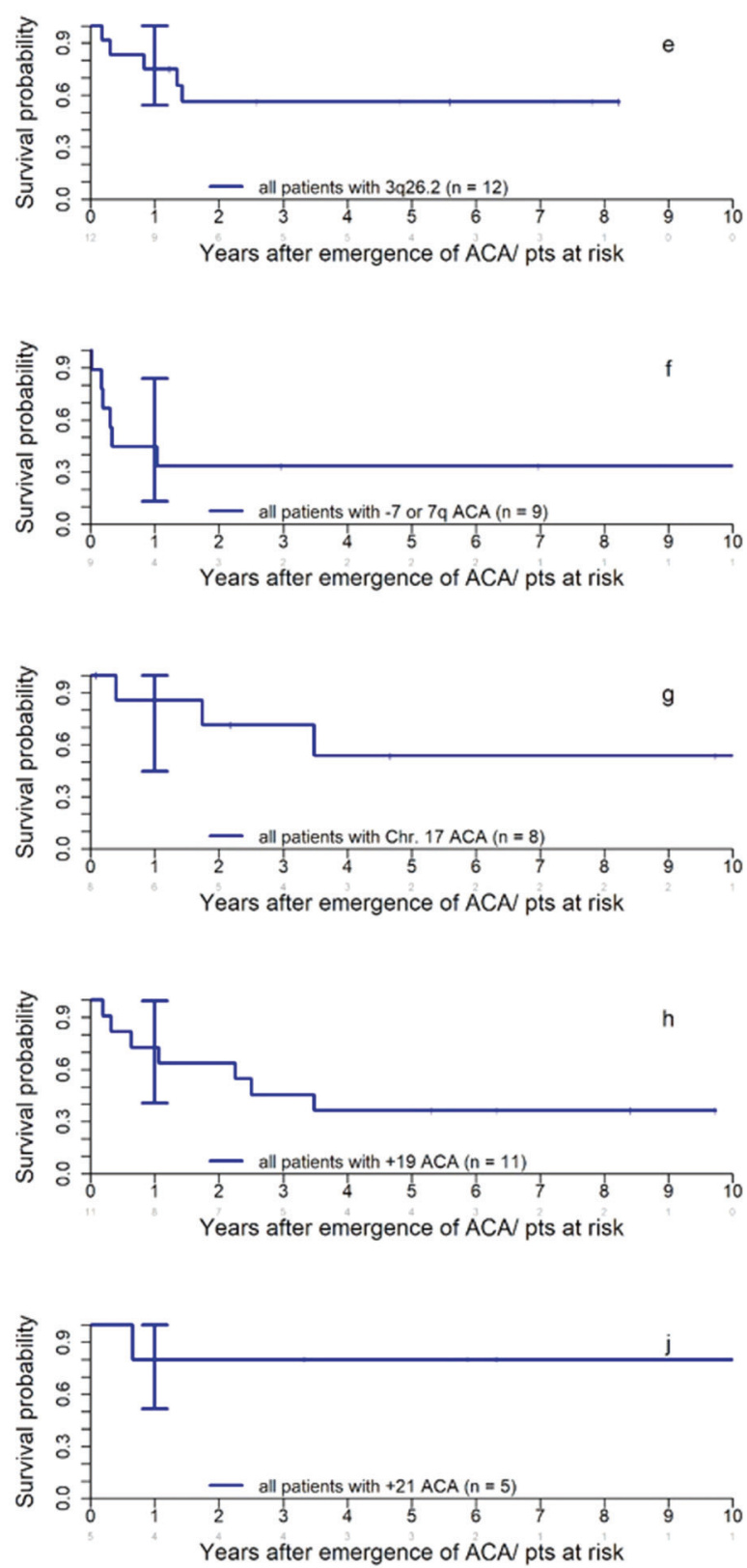

ACA. Suvival after emergence of low-risk ACA in imatinib-treated patients serves as control. The right-side panel shows the impact of rare high-risk ACA of chromosomes 3, 7, 17, 19, and 21 on survival $(\mathbf{e}-\mathbf{i})$.

(Fig. 3b) when only patients with low blast levels of $1-5 \%$ were considered. When restricting the cohorts to larger blast increases, the effect of high-risk ACA on the hazard to die decreased. In the last cohorts of patients with blast increases to at least $20 \%$ or $30 \%$, no difference between patients with and without high-risk ACA was found (hazard ratio: 0.83, 95\% CI: 0.50-2.89). The hazard ratios for low-risk ACA compared to no ACA were increased to much lesser extents than for high-risk ACA. 
Table 3 Hazard to die in IMtreated patients with high- and low-risk ACA dependent on blast increase to $1-30 \%$ (Cox model).

\begin{tabular}{|c|c|c|c|c|c|}
\hline & HR & Lower $95 \%$ CI & Upper 95\% CI & $P$ value & $n$ \\
\hline \multicolumn{6}{|l|}{ Peripheral blood (PB) } \\
\hline \multicolumn{6}{|l|}{$1 \%$ blasts in $\mathrm{PB}$} \\
\hline Presence of high-risk ACAs & 3.65 & 2.32 & 5.75 & $<0.001$ & \multirow[t]{2}{*}{224} \\
\hline Presence of low-risk ACAs & 1.92 & 1.06 & 8.07 & 0.039 & \\
\hline \multicolumn{6}{|l|}{$5 \%$ blasts in $\mathrm{PB}$} \\
\hline Presence of high-risk ACAs & & 1.11 & 2.86 & 0.016 & \multirow[t]{2}{*}{117} \\
\hline Presence of low-risk ACAs & 1.77 & 0.68 & 4.66 & 0.244 & \\
\hline \multicolumn{6}{|l|}{$10 \%$ blasts in $\mathrm{PB}$} \\
\hline Presence of high-risk ACAs & 1.39 & 0.87 & 2.21 & 0.167 & \multirow[t]{2}{*}{107} \\
\hline Presence of low-risk ACAs & 1.38 & 0.53 & 3.60 & 0.506 & \\
\hline \multicolumn{6}{|l|}{$15 \%$ blasts in $\mathrm{PB}$} \\
\hline Presence of high-risk ACAs & 1.37 & 0.86 & 2.19 & 0.189 & \multirow[t]{2}{*}{104} \\
\hline Presence of low-risk ACAs & 1.32 & 0.51 & 3.42 & 0.568 & \\
\hline \multicolumn{6}{|l|}{$20 \%$ blasts in PB } \\
\hline Presence of high-risk ACAs & 0.84 & 0.50 & 1.40 & 0.502 & \multirow[t]{2}{*}{79} \\
\hline Presence of low-risk ACAs & 0.74 & 0.20 & 2.71 & 0.652 & \\
\hline \multicolumn{6}{|l|}{$30 \%$ blasts in $\mathrm{PB}$} \\
\hline Presence of high-risk ACAs & 0.83 & 0.50 & 1.39 & 0.479 & \multirow[t]{2}{*}{78} \\
\hline Presence of low-risk ACAs & 0.76 & 0.20 & 2.89 & 0.689 & \\
\hline \multicolumn{6}{|l|}{ Bone marrow (BM) } \\
\hline \multicolumn{6}{|l|}{$1 \%$ blasts in $\mathrm{BM}$} \\
\hline Presence of high-risk ACAs & 6.12 & 4.08 & 9.17 & $<0.001$ & \multirow[t]{2}{*}{1033} \\
\hline Presence of low-risk ACAs & 2.71 & 0.99 & 7.44 & 0.053 & \\
\hline \multicolumn{6}{|l|}{$5 \%$ blasts in $\mathrm{BM}$} \\
\hline Presence of high-risk ACAs & 5.46 & 3.58 & 8.33 & $<0.001$ & \multirow[t]{2}{*}{588} \\
\hline Presence of low-risk ACAs & 3.21 & 1.16 & 8.85 & 0.024 & \\
\hline \multicolumn{6}{|l|}{$10 \%$ blasts in $\mathrm{BM}$} \\
\hline Presence of high-risk ACAs & 2.21 & 1.37 & 3.56 & 0.001 & \multirow[t]{2}{*}{134} \\
\hline Presence of low-risk ACAs & 1.68 & 0.61 & 4.60 & 0.311 & \\
\hline \multicolumn{6}{|l|}{$15 \%$ blasts in $\mathrm{BM}$} \\
\hline Presence of high-risk ACAs & 1.77 & 1.11 & 2.83 & 0.017 & \multirow[t]{2}{*}{115} \\
\hline Presence of low-risk ACAs & 1.66 & 0.63 & 4.37 & 0.309 & \\
\hline \multicolumn{6}{|l|}{$20 \%$ blasts in $\mathrm{BM}$} \\
\hline Presence of high-risk ACAs & 1.24 & 0.74 & 2.06 & 0.416 & \multirow[t]{2}{*}{87} \\
\hline Presence of low-risk ACAs & 1.11 & 0.29 & 4.18 & 0.882 & \\
\hline \multicolumn{6}{|l|}{$30 \%$ blasts in $\mathrm{BM}$} \\
\hline Presence of high-risk ACAs & 0.89 & 0.53 & 1.49 & 0.665 & \multirow[t]{2}{*}{79} \\
\hline Presence of low-risk ACAs & 0.81 & 0.21 & 3.07 & 0.760 & \\
\hline
\end{tabular}

\section{Course of disease and causes of death}

Thirty-seven patients with high-risk ACA (41\%) died (Flow chart, Fig. 1a, c). The causes of death were known for 34 patients and almost exclusively CML related. Thirty-two patients (94\%) died of progression, mostly in BC, including 21 after progression-related transplantation $(15$ in $\mathrm{BC}, 1$ in AP, 2 after loss of cytogenetic remission, 2 because of no molecular response, and 1 with unknown indication). Two patients died of CML-unrelated causes.
Of $54(59 \%)$ living patients with high-risk ACAs, 21 ( $23 \%$ of total) were transplanted, 8 of these in BC, 2 in AP, 9 because of no molecular response, and 2 with unknown indication. Five $(5 \%)$ non-transplanted patients are alive after progression (Flow chart, Fig. 1a, c). Twenty-eight patients $(31 \%)$ are alive without documented progression 0-11 years after emergence of high-risk ACA.

Of the four patients with low-risk ACA who died, three died of CML-related (one after SCT) and one of CMLunrelated causes 

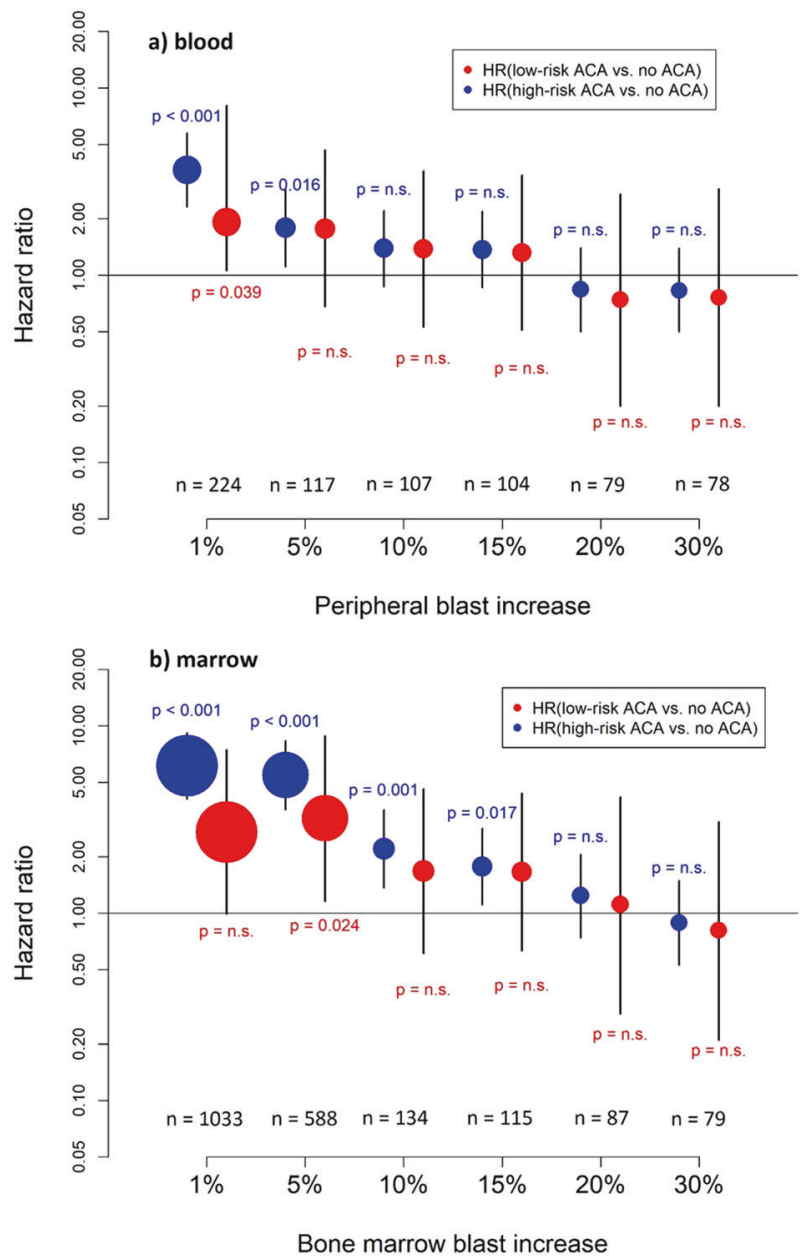

Fig. 3 Hazard to die with high-risk and low-risk ACA compared to no ACA dependent on blast counts. Hazard ratios for mortality in imatinib-treated patients with high-risk and low-risk ACA were determined in six different (but overlapping) patient groups (blast increase to $1-30 \%$ ) together with $95 \%$ confidence intervals a in peripheral blood and $\mathbf{b}$ in bone marrow. The size of the circle correlates with the sample size. Thirty-seven patients with high-risk ACA and four patients with low-risk ACA died. In 34 patients with high-risk ACA, causes of death were known. Thirty-two of these (94\%) died of progression, including progression-related transplantation in 21 patients. Two patients died of CML-unrelated causes. Causes of death were unknown in three patients. With low-risk ACA, causes of death were CML related in three patients and unknown in one patient.

\section{Discussion}

We here report that the combination of high-risk ACA and low-level blasts heralds progression and death by CML. This finding has implications for diagnosis and management of patients in end-phase CML. High-risk ACAs allow to identify CML end-phase at an earlier time than is possible with the current blast thresholds $[9,10]$. These patients require a change of therapy and/or more intensive treatments, for example, with ponatinib or allogeneic SCT [9]. A clinically relevant, but in 39 patients not statistically significant difference of $30 \%$ 2-year survival suggests that outcome of transplanted patients with high-risk ACA depends on disease stage similar to patients without ACA [12]. Successful treatment may explain, at least in part, the plateau phase of survival curves after 4 years.

High-risk ACA at low blast counts are not an indicator of $\mathrm{AP}$ as previously reviewed [31, 32], but a marker of progression and death by CML regardless whether they are present at diagnosis or emerge in the course of disease. Sixty-nine percent of patients with high-risk ACA and low blast levels progressed or died of CML during the observation period. This includes transplanted patients who as a rule were transplanted because of progression. Our findings agree with an earlier observation that patients in AP with ACA and blast increase have a worse outcome [33].

Our data suggest that the appropriate time for a change of treatment is emergence of high-risk ACA rather than waiting for an increase of blasts.

High-risk ACA include, in addition to major route ACA (which were defined solely on the basis of their frequency in BC) [1-2], most notably $-7 / 7 \mathrm{q}-, 3 \mathrm{q} 26.2$, and $11 \mathrm{q} 23$ rearrangements and complex karyotypes [16-21, 26]. Additional high-risk ACA may surface on continued clinical and cytogenetic scrutiny.

Our definition of high-risk ACA largely agrees with that proposed by others $[17,21]$, but there are differences. The prognosis with +8 alone, although clearly better than with +8 in combination, is still worse than with low-risk ACA (Fig. 2a). We thus have included +8 alone in the high-risk ACA group. $+\mathrm{Ph}$ has an equally unfavorable impact on survival, regardless whether it occurs as a single aberration or in combination (Fig. 2b). In agreement with earlier reports [17, 18], chromosome 19 aberrations exclusively occurred in combination, whereas $3 \mathrm{q} 26.2$ was mostly found as a single aberration and rarely at diagnosis [16]. $-\mathrm{Y}$ in our analyses had a prognosis not different from no ACA.

Looking at our data in context of the literature [17, 21], a risk stratification of ACA in two risk-groups (high risk with impact on survival and low risk with little or no impact) seems useful for clinical purposes. Due to the limited sample size and the exploratory nature of this work, we would welcome verification of these results by others.

High-risk ACAs were not observed in all BC patients. We cannot rule out that other events such as genetic alterations not detectable by cytogenetics predispose to a blast increase. Gene sequencing detects such alterations [34]. Telomere shortening [35] or increased separase activity [36] may contribute to progression. Likewise, lowrisk ACA might include some hitherto unrecognized highrisk ACA as suggested by the three patients with $\mathrm{BC}$ and low-risk ACA.

High-risk ACAs were observed in $6 \%$ of $\mathrm{CP}$ patients, but in $61 \%$ of patients who had progressed to $\mathrm{BC}$, whereas lowrisk ACAs were observed in $2.1 \%$ of $\mathrm{CP}$ patients and in 
$2.8 \%$ of patients with BC. This is strong support for a role of high-risk ACA in the evolution of CML and is in line with the hypothesis that BCR-ABL1 predisposes to ACA, which then promote progression. The emergence of highrisk ACA might anticipate and define the point of no return in the evolution of CML indicating non-reversibility by tyrosine kinase inhibitor (TKI). High-risk ACA could emerge as testable cause of non-mutation-related TKI resistance.

A limitation of this study is the follow-up cytogenetics, which have been replaced in many instances by molecular testing increasingly done in the course of the study. Furthermore, most cytogenetic analyses were performed in the first months after diagnosis or when the patients' conditions were worsening. This might introduce a bias, as patients doing well were usually not analyzed. Also, it is possible that analyses with low numbers of mitoses miss ACA and that the true percentage of patients with ACA is underestimated.

Although the low number of follow-up cytogenetics has limited the direct correlation of ACA with blast increase, it points to the strength of the evidence for the association of high-risk ACA with end-phase CML and survival in the Cox model in spite of missing values.

A correlation with BCR-ABL1 transcript numbers was not conclusive because of too few molecular measurements at early blast increase.

A strength of the study is the size of the cohort as one of the largest of TKI-treated CP-CML patients on whom emergence of $\mathrm{ACA}$ and progression to $\mathrm{BC}$ were prospectively recorded in parallel over prolonged periods of time. The association of high-risk ACA with progression would not be so obvious in smaller cohorts with shorter observation.

In conclusion, high-risk ACAs are an early marker of CML progression. In the presence of low blast levels, highrisk ACAs indicate death by CML earlier than is possible with standard blast thresholds. An appropriate time for a change of therapy may be emergence of high-risk ACA rather than waiting for an increase of blasts. Cytogenetic monitoring is indicated when signs of progression surface and response to therapy is unsatisfactory.

Acknowledgements We thank E Matzat, R Pleil-Lösch, I Stalljann, G Bartsch, C Sodan-Boyer, A Elett, M Meckesheimer, U Böhm, and $\mathrm{J}$ Hehlmann for assistance.

The SAKK and the German CML Study Group L. Fischer von Weikersthal $^{17}$, M. Hahn ${ }^{18}$, G. Schlimok ${ }^{19}$, D. Reichert ${ }^{20}$, J. Janssen ${ }^{20}$, U. Martens ${ }^{21}$, P. Majunke ${ }^{22}$, Peter Reichert ${ }^{23}$, K. Neben ${ }^{24}$, S. Kor$\operatorname{sten}^{25}$, Ch. Scholz ${ }^{26}$, B. Oldenkott ${ }^{27}$, J. Heßling ${ }^{28}$, D. Kingreen ${ }^{29}$, C. Sperling ${ }^{30}$, C. Schelenz ${ }^{30}$, I. Blau ${ }^{31}$, A. Urmersbach ${ }^{32}$, W. Ludwig $^{33}$, P. Le Coutre ${ }^{34}$, R. Arnold ${ }^{34}$, M. de Wit ${ }^{35}$, A. Pezzutto ${ }^{36}$, E. Schäfer ${ }^{37}$, R. Schroers ${ }^{38}$, A. Lochter ${ }^{38}$, D. Behringer ${ }^{39}$, Y. Ko ${ }^{40}$, S. Weidenhöfer ${ }^{40}$, W. Verbeek $^{41}$, P. Brossart ${ }^{42}$, G. Trenn ${ }^{43}$,
W. Pommerien ${ }^{44}$, J. Krauter ${ }^{45}$, G. Doering ${ }^{46}$, H. Munzinger ${ }^{46}$, C. Diekmann ${ }^{47}$, B. Hertenstein ${ }^{48}$, S. Stier ${ }^{49}$, F. Möller-Faßbender ${ }^{50}$, M. Hänel ${ }^{51}$, T. Zöller ${ }^{52}$, C. Lamberti ${ }^{53}$, B. $\mathrm{Koch}^{54}$, A. Henzel ${ }^{55}$, S. Wagner ${ }^{56}$, A. Schmalenbach ${ }^{57}$, M. Hoffknecht ${ }^{58}$, G. Ehninger ${ }^{59}$, A. Kiani ${ }^{59}$, T. Illmer ${ }^{60}$ C. Aul ${ }^{61}$, M. Flaßhove ${ }^{62}$, F. Henneke ${ }^{62}$, M. Simon ${ }^{63}$, L. Müller ${ }^{64}$, H. Becker ${ }^{64}$, R. Janz ${ }^{65}$, M. J. Eckart ${ }^{66}$, R. Fuchs ${ }^{67}$, F. Schlegel ${ }^{67}$, M. Wattad ${ }^{68}$, R. Rudolph ${ }^{69}$, D. W. Beelen ${ }^{70}$, A. Lindemann ${ }^{71}$, D. Linck ${ }^{72}$, Wassman ${ }^{73}$, E. Jäger ${ }^{74}$, S. Al-Batran ${ }^{74}$, T. Reiber ${ }^{75}$, C. F. Waller ${ }^{76}$, H. Hoeffkes ${ }^{77}$, L. Schulz ${ }^{78}$, K. Tajrobehkar $^{79}$, J. Mittermüller ${ }^{80}$, H. Pralle ${ }^{81}$, V. Runde ${ }^{82}$, A. Hoyer ${ }^{83}$, H. Tessen ${ }^{83}$, L. Trümper ${ }^{84}$, C. Schmidt ${ }^{85}$, M. Sieber ${ }^{86}$, H. Eschenburg $^{87}$, R. Depenbusch ${ }^{88}$, S. Rösel ${ }^{88}$, H. W. Lindemann ${ }^{89}$, H. Wolf $^{90}$, C. Spohn ${ }^{91}$, R. Moeller ${ }^{11}$, D. Hossfeld ${ }^{92}$, A. Zander ${ }^{92}$, P. Schafhausen ${ }^{92}$, H. Köster ${ }^{93}$, W. Hollburg ${ }^{94}$, N. Schmitz ${ }^{95}$, H. Dürk ${ }^{96}$, M. Hemeier ${ }^{96}$, A. Grote-Metke ${ }^{97}$, H. Weischer ${ }^{97}$, B. Bechtel ${ }^{97}$, L. Balleisen ${ }^{98}$, M. Sosada ${ }^{99}$, A. $\mathrm{Ho}^{100}$, V. Petersen ${ }^{101}$, J. Dengler ${ }^{102}$, S. Bildat ${ }^{103}$, L. Hahn ${ }^{104}$, H. Dietzfelbinger ${ }^{105}$, W. Gröschel ${ }^{106}$, A. Bartholomäus ${ }^{107}$, W. Freier ${ }^{108}$, B. Sievers ${ }^{108}$, I.-M. Pfreundschuh ${ }^{109}$, T. Herrmann ${ }^{110}$, A. Fauser ${ }^{110}$, J. Menzel ${ }^{111}$, M. Kemmerling ${ }^{112}$, R. Hansen ${ }^{113}$, H. Link ${ }^{114}$, M. Schatz ${ }^{115}$, M. Bentz ${ }^{116}$, O. Prümmer ${ }^{117}$, M. Kneba ${ }^{118}$, J. Heymanns ${ }^{119}$, S. Schmitz ${ }^{120}$, C. Scheid ${ }^{121}$, A. Lollert ${ }^{122}$, M. Neise ${ }^{122}$, M. Planker ${ }^{123}$, M. Stauch ${ }^{124}$, M. Schröder ${ }^{125}$, B. Kempf ${ }^{126}$, U. VehlingKaiser $^{127}$, S. Kremers ${ }^{128}$, G. Köchling ${ }^{129}$, L. Müller ${ }^{130}$, F. Hartmann ${ }^{131}$, T. Neuhaus ${ }^{132}$, S. Fetscher ${ }^{133}$, D. Kämpfe ${ }^{134}$, G. Heil ${ }^{135}$, M. Uppenkamp $^{136}$, B. Goldmann ${ }^{137}$, T. Fischer Huber ${ }^{138}$, U. Hieber ${ }^{139}$, C. Plöger $^{140}$, M. Griesshammer ${ }^{141}$, C. Lange ${ }^{142}$, B. Göttler ${ }^{143}$, C. Lunscken ${ }^{144}$, X. Schiel ${ }^{145}$, C. Scheidegger ${ }^{146}$, O. Stötzer ${ }^{147}$, H. Hitz ${ }^{148}$, H. Schick ${ }^{149}$, S. Völkl ${ }^{150}$ K. Spiekermann ${ }^{151}$, W. Berdel ${ }^{152}$, H. Hebart ${ }^{153}$, E. Ladda $^{154}$, P. Schmidt ${ }^{155}$, U. Burkhardt ${ }^{155}$, S. Hentschke ${ }^{156}$, C. Falge ${ }^{157}$, D. Reschke ${ }^{158}$, C. A. Köhne ${ }^{159}$, C. Müller-Naendrup ${ }^{160}$, M. Sauer ${ }^{161}$, S. Frühauf ${ }^{162}$, K. Ranft ${ }^{163}$, Y. Dencausse ${ }^{164}$, B. Sandritter $^{165}$, G. Baake ${ }^{166}$, M. Hofknecht ${ }^{167}$, R. Dengler ${ }^{168}$, M. Edinger ${ }^{169}$, M. Schenk ${ }^{170}$, A. Wehmeier ${ }^{171}$, H.-P. Weidelich ${ }^{172}$, R. Pihusch ${ }^{173}$, K. Stahlhut ${ }^{174}$, M. Baldus ${ }^{175}$, A. Matzdorff ${ }^{176}$, T. Geer ${ }^{177}$, S. Schanz ${ }^{178}$, G. Käfer ${ }^{179}$, W. Gassmann ${ }^{180}$, C. Priebe-Richter ${ }^{181}$, M. Demandt ${ }^{182}$, G. Springer ${ }^{183}$, H. Fiechtner ${ }^{183}$, C. Denzlinger ${ }^{184}$, J. Schleicher ${ }^{185}$, D. Assman ${ }^{186}$, R. Gaeckler ${ }^{187}$, G. Adam ${ }^{188}$, A. Waladkhani ${ }^{189}$, B. Rendenbach ${ }^{190}$, H. Forstbauer ${ }^{191}$, L. Kanz ${ }^{192}$, S. Jacki ${ }^{193}$, F. Stegelmann $^{193}$, N. Kalhori ${ }^{194}$, A. Nusch ${ }^{194}$, W. Langer ${ }^{194}$, F. Müller ${ }^{195}$, S. Brettner ${ }^{196}$, B. Uebelmesser ${ }^{197}$, T. Kamp ${ }^{198}$, C. Schadeck-Gressel ${ }^{199}$, K. Josten ${ }^{200}$, O. Klein ${ }^{200}$, R. Schwerdtfeger ${ }^{201}$, H. Baurmann ${ }^{201}$, H. Strotkötter ${ }^{202}$, W. Fett ${ }^{203}$, A. Raghavachar ${ }^{204}$, C. Maintz ${ }^{205}$, M. C. Goebler ${ }^{206}$, R. Schlag ${ }^{207}$, W. Elsel ${ }^{208}$, M. Wernli ${ }^{209}$, D. Heim ${ }^{210}$, W. Wuillemin ${ }^{211}$, U. Hess ${ }^{212}$, J. Gmür ${ }^{213}$, J. Mayer ${ }^{214}$.

${ }^{17}$ Klinikum St. Marien, Amberg, Germany; ${ }^{18}$ Ambulantes Onkologiezentrum, Ansbach, Germany; ${ }^{19}$ Klinikum, Augsburg, Germany; ${ }^{20}$ Gemeinschaftspraxis für Hämatologie und Onkologie, Aurich, Germany; ${ }^{21}$ Klinikum am Plattenwald, Bad Friedrichshall, Germany; ${ }^{22}$ Klinikum, Bad Hersfeld, Germany; ${ }^{23}$ Helios Klinikum, Bad Saarow, Germany; ${ }^{24}$ Stadtklinik, Baden-Baden, Germany; ${ }^{25}$ Vinzenz Pallotti Hospital Bensberg, Bergisch Gladbach, Germany; ${ }^{26}$ Vivantes Krankenhaus Am Urban, Berlin, Germany; ${ }^{27}$ St. HedwigKrankenhaus, Berlin, Germany; ${ }^{28}$ Praxis für Innere Medizin, Berlin, Germany; ${ }^{29}$ Onkologische Schwerpunktpraxis Tiergarten, Berlin, Germany; ${ }^{30}$ Onkologische Schwerpunktpraxis Berlin-Mitte, Berlin, Germany; ${ }^{31}$ Onkologische Praxis am Gesundbrunnen, Berlin, Germany; ${ }^{32}$ MVZ Hämatologie Onkologie Tempelhof, Berlin, Germany; ${ }^{33}$ Helios Klinikum Buch, Berlin, Germany; ${ }^{34}$ Charité-Campus Virchow, Berlin, Germany; ${ }^{35}$ Vivantes Klinikum Neukölln, Berlin, Germany; ${ }^{36}$ Campus Benjamin Franklin, Berlin, Germany; ${ }^{37}$ Onkologische Schwerpunktpraxis, Bielefeld, Germany; ${ }^{38}$ Universitätsklinik Knappschaftskrankenhaus, Bochum, Germany; ${ }^{39}$ Augusta-Kranken-Anstalt, Bochum, Germany; ${ }^{40}$ Johanniter-Krankenhaus, Bonn, Germany; ${ }^{41}$ Zentrum für ambulante 
Hematologie und Onkologie, Bonn, Germany; ${ }^{42}$ Medizinische Klinik III, Bonn, Germany; ${ }^{43}$ Knappschaftskrankenhaus, Bottrop, Germany; ${ }^{44}$ Städtisches Klinikum, Brandenburg, Germany; ${ }^{45}$ Klinikum, Braunschweig, Germany; ${ }^{46}$ Gemeinschaftspraxis für Hämatologie und Onkologie, Bremen, Germany; ${ }^{47}$ DIAKO, Bremen, Germany; ${ }^{48} \mathrm{Kli}-$ nikum Bremen Mitte, Bremen, Germany; ${ }^{49}$ Onkologische Schwerpunktpraxis, Brühl, Germany; ${ }^{50}$ Lukas Krankenhaus, Bünde, Germany; ${ }^{51}$ Klinik für Innere Medizin 3, Chemnitz, Germany; ${ }^{52}$ Onkologische Schwerpunktpraxis, Coburg, Germany; ${ }^{53}$ Klinikum, Coburg, Germany; ${ }^{54}$ St. Vincenz Krankenhaus, Datteln, Germany; ${ }^{55}$ Krankenhaus Maria Hilf, Daun, Germany; ${ }^{56}$ Klinikum, Deggendorf, Germany; ${ }^{57}$ Städtische Kliniken, Delmenhorst, Germany; ${ }^{58}$ Praxis für Hämatologie und Onkologie, Dernbach, Germany; ${ }^{59}$ Universitätsklinikum Carl Gustav Carus, Dresden, Germany; ${ }^{60}$ Gemeinschaftspraxis Hämatologie - Onkologie, Dresden, Germany; ${ }^{61}$ HELIOS St. Johannes Klinik, Duisburg, Germany; ${ }^{62}$ Krankenhaus, Düren, Germany; ${ }^{63}$ Internistische Praxisgemeinschaft, Ehingen, Germany; ${ }^{64}$ Onkologische Schwerpunktpraxis Leer, Emden, Germany; ${ }^{65}$ Praxis für Innere Medizin, Hämatologie und Onkologie, Erkelenz, Germany; ${ }^{66}$ Internistische Schwerpunktpraxis, Erlangen, Germany; ${ }^{67}$ St. Antonius Hospital, Eschweiler, Germany; ${ }^{68}$ Kliniken Süd, Essen, Germany; ${ }^{69}$ Hämatologisch-Onkologische Gemeinschaftspraxis, Essen, Germany; ${ }^{70}$ Klinik für Knochenmarktransplantation, Essen, Germany; ${ }^{71}$ Praxis für Innere Medizin, Ettlingen, Germany; ${ }^{72}$ Praxiskooperation, Euskirchen, Germany; ${ }^{73}$ Universitätsklinikum, Frankfurt am Main, Germany; ${ }^{74}$ Krankenhaus Nordwest, Frankfurt am Main, Germany; ${ }^{75}$ Onkologische Praxis, Freiburg, Germany; ${ }^{76}$ Universitätsklinikum, Freiburg, Germany; ${ }^{77}$ Klinikum, Fulda, Germany; ${ }^{78}$ Klinikum, GarmischPartenkirchen, Germany; ${ }^{79}$ Praxis für Innere Medizin, Geilenkirchen, Germany; ${ }^{80}$ Gemeinschaftspraxis für Hämatologie und Onkologie, Germering, Germany; ${ }^{81}$ Universitätsklinikum, Gießen, Germany; ${ }^{82}$ Wilhelm-Anton-Hospital, Goch, Germany; ${ }^{83}$ Onkologische Kooperation Harz, Goslar, Germany; ${ }^{84}$ Universitätsmedizin, Göttingen, Germany; ${ }^{85}$ Universitätsklinikum, Greifswald, Germany; ${ }^{86}$ Kreiskrankenhaus, Gummersbach, Germany; ${ }^{87}$ Onkologische Schwerpunktpraxis, Güstrow, Germany; ${ }^{88}$ Onkologische Schwerpunktpraxis, Gütersloh, Germany; ${ }^{89}$ St. MarienHospital, Hagen, Germany; ${ }^{90}$ Universitätsklinikum, Halle/ Saale, Germany; ${ }^{91}$ Hämatologisch - Onkologische Gemeinschaftspraxis, Halle/Saale, Germany; ${ }^{92}$ Universitätsklinikum Eppendorf, Hamburg, Germany; ${ }^{93}$ Hämatologisch-onkologisches Zentrum Ost, Hamburg, Germany; ${ }^{94}$ Hämatologisch-onkologische Praxis Altona, Hamburg, Germany; ${ }^{95}$ Allg. Krankenhaus St. Georg, Hamburg, Germany; ${ }^{96}$ St. Marien-Hospital, Hamm, Germany; ${ }^{97}$ Hämatologische Gemeinschaftspraxis, Hamm, Germany; ${ }^{98}$ Evangelisches Krankenhaus, Hamm, Germany; ${ }^{99}$ Klinikum Siloah, Hannover, Germany; ${ }^{100}$ Universitätsklinikum, Heidelberg, Germany; ${ }^{101}$ Praxis für Innere Medizin, Heidenheim, Germany; ${ }^{102}$ Onkologische Schwerpunktpraxis, Heilbronn, Germany; ${ }^{103}$ Medizinische Klinik II, Herford, Germany; ${ }^{104}$ Praxisklinik, Herne, Germany; ${ }^{105}$ Praxis für Hämatologie und Onkologie, Herrsching-Ammersee, Germany; ${ }^{106}$ Onkologische Schwerpunktpraxis, Hersbruck, Germany; ${ }^{107} \mathrm{St}$. Bernward Krankenhaus, Hildesheim, Germany; ${ }^{108}$ Onkologie im Medicinum, Hildesheim, Germany; ${ }^{109}$ Klinik für Innere Medizin, Homburg, Germany; ${ }^{110}$ Klinikum, Idar-Oberstein, Germany; ${ }^{111} \mathrm{Kli}$ nikum, Ingolstadt, Germany; ${ }^{112} \mathrm{MVZ}$ am Ev. Krankenhaus Bethanien, Iserlohn, Germany; ${ }^{113}$ Hämatologisch-Onkologische Praxis, Kaiserslautern, Germany; ${ }^{114}$ Westpfalzklinikum, Kaiserslautern, Germany; ${ }^{115}$ St. Vincentius-Kliniken, Karlsruhe, Germany; ${ }^{116}$ Städtisches Klinikum, Karlsruhe, Germany; ${ }^{117}$ Klinikum Oberallgäu, Kempten, Germany; ${ }^{118}$ Universitätsklinikum, Kiel, Germany; ${ }^{119}$ Praxisklinik für Hematologie und Onkologie, Koblenz, Germany; ${ }^{120}$ Praxis für Hämatologie und Internistische Onkologie, Köln, Germany; ${ }^{121}$ Universitätsklinikum, Köln, Germany; ${ }^{122}$ Onkologische Gemeinschaftspraxis, Krefeld, Germany;
${ }^{123}$ Klinikum, Krefeld, Germany; ${ }^{124}$ Onkologische Schwerpunktpraxis, Kronach, Germany; ${ }^{125}$ Vinzentiuskrankenhaus, Landau, Germany; ${ }^{126}$ Klinikum, Landshut, Germany; ${ }^{127}$ Internistische Gemeinschaftspraxis, Landshut, Germany; ${ }^{128}$ Caritas-Krankenhaus, Lebach, Germany; ${ }^{129}$ Kreiskrankenhaus, Leer, Germany; ${ }^{130}$ Onkologie UnterEms, Leer, Germany; ${ }^{131}$ Klinikum, Lemgo, Germany; ${ }^{132}$ St. Vincenz Krankenhaus, Limburg, Germany; ${ }^{133}$ Sana Kliniken, Lübeck, Germany; ${ }^{134}$ Praxis für Hämatologie/Onkologie, Lüdenscheid, Germany; ${ }^{135}$ Klinikum, Lüdenscheid, Germany; ${ }^{136} \mathrm{Kli}-$ nikum Ludwigshafen, Ludwigshafen, Germany; ${ }^{137}$ Onkologische Schwerpunktpraxis, Lüneburg, Germany; ${ }^{138}$ Universitätsmedizin, Mainz, Germany; ${ }^{139}$ Praxis für Innere Medizin, Mannheim, Germany; ${ }^{140}$ Onkologie Praxis, Mannheim, Germany; ${ }^{141}$ Johannes Wesling Klinikum, Minden, Germany; ${ }^{142}$ Krankenhaus St. Franziskus, Mönchengladbach, Germany; ${ }^{143}$ Onkologische Schwerpunktpraxis, Muhr am See, Germany; ${ }^{144}$ Praxis für Innere Medizin, Mülheim, Germany; ${ }^{145}$ Städtisches Klinikum Harlaching, München, Germany; ${ }^{146}$ Praxis für Innere Medizin und HämatoOnkologie, München, Germany; ${ }^{147}$ Onkologische Schwerpunktpraxis, München, Germany; ${ }^{148}$ Hämatologische Schwerpunktpraxis, München, Germany; ${ }^{149}$ Hämatologische Praxisgemeinschaft, München, Germany; ${ }^{150}$ Onkologische Schwerpunktpraxis, München, Germany; ${ }^{151}$ Universitätsklinikum Großhadern, München, Germany; ${ }^{152}$ Universitätsklinikum, Münster, Germany; ${ }^{153}$ Stauferklinikum Schwäbisch Gmünd, Mutlangen, Germany; ${ }^{154}$ Onkologische Schwerpunktpraxis, Neumarkt, Germany; ${ }^{155}$ Onkologische Schwerpunktpraxis, Neunkirchen, Germany; ${ }^{156}$ Hämatoonkologisches Zentrum, Norderstedt, Germany; ${ }^{157}$ Medizinische Klinik 5, Nürnberg, Germany; ${ }^{158}$ Onkologische Praxis, Oldenburg, Germany; ${ }^{159}$ Klinikum, Oldenburg, Germany; ${ }^{160}$ Onkologische Schwerpunktpraxis, Olpe, Germany; ${ }^{161}$ Martinus-Hospital, Olpe, Germany; ${ }^{162}$ Paracelsus Klinik, Osnabrück, Germany; ${ }^{163}$ Städtisches Krankenhaus, Penzberg, Germany; ${ }^{164} \mathrm{MVZ}$ am Siloah St. Trudpert Klinikum, Pforzheim, Germany; ${ }^{165}$ Klinikum, Pforzheim, Germany; ${ }^{166}$ Onkologische Praxis, Pinneberg, Germany; ${ }^{167}$ Elisabeth Krankenhaus, Recklinghausen, Germany; ${ }^{168}$ Schwerpunktpraxis für Hämatologie und Onkologie, Regensburg, Germany; ${ }^{169}$ Universitätsklinikum, Regensburg, Germany; ${ }^{170}$ Krankenhaus Barmherzige Brüder, Regensburg, Germany; ${ }^{171}$ Sana Klinikum, Remscheid, Germany; ${ }^{172}$ Klinikum am Steinenberg, Reutlingen, Germany; ${ }^{173}$ Internistische Gemeinschaftspraxis, Rosenheim, Germany; ${ }^{174}$ Immanuel Klinik, Rüdersdorf, Germany; ${ }^{175}$ Internistische Schwerpunktpraxis, Rüsselsheim, Germany; ${ }^{176} \mathrm{Car}-$ itasKlinikum St. Theresia, Saarbrücken, Germany; ${ }^{177}$ Diakonie Hospital, Schwäbisch Hall, Germany; ${ }^{178}$ Kreisklinikum, Siegen, Germany; ${ }^{179}$ Kreiskrankenhaus, Sigmaringen, Germany; ${ }^{180}$ St. MarienKrankenhaus, Siegen, Germany; ${ }^{181}$ Hämatologische und Onkologische Praxis, Stadthagen, Germany; ${ }^{182} \mathrm{MVZ}$ Onkologie am Klinikum Straubing, Straubing, Germany; ${ }^{183}$ Praxis für Onkologie und Hämatologie, Stuttgart, Germany; ${ }^{184}$ Marienhospital, Stuttgart, Germany; ${ }^{185}$ Katharinenhospital, Stuttgart, Germany; ${ }^{186}$ Diakonie-Klinikum Stuttgart, Stuttgart, Germany; ${ }^{187}$ Bürgerhospital, Stuttgart, Germany; ${ }^{188}$ Asklepios Klinik, Triberg, Germany; ${ }^{189}$ Klinikum Mutterhaus der Borromäerinnen, Trier, Germany; ${ }^{190}$ Internistische Gemeinschaftspraxis, Trier, Germany; ${ }^{191}$ Hämatologisch-Onkologische Schwerpunktpraxis, Troisdorf, Germany; ${ }^{192}$ Universitätsklinikum, Tübingen, Germany; ${ }^{193}$ Internistische Praxis, Tübingen, Germany; ${ }^{194}$ Universitätsklinikum, Ulm, Germany; ${ }^{195}$ Gemeinschaftspraxis für Hämatologie und Onkologie, Velbert, Germany; ${ }^{196}$ Praxis für Innere Medizin, Verden, Germany; ${ }^{197}$ Kreiskrankenhaus, Waldbröl, Germany; ${ }^{198}$ Hämatologische Praxis, Weiden, Germany; ${ }^{199}$ Praxis für Innere Medizin, Wendlingen, Germany; ${ }^{200}$ Schwerpunktpraxis für Hämatologie/Onkologie, Wesel, Germany; ${ }^{201}$ Praxis für Hämatologie und Onkologie, Wiesbaden, Germany; ${ }^{202}$ Deutsche Klinik für Diagnostik, Wiesbaden, Germany; ${ }^{203}$ Praxis für Hämatologie und internistische Onkologie, Wuppertal, Germany; 
${ }^{204}$ Klinikum, Wuppertal, Germany; ${ }^{205}$ Hämatologisch-Onkologische Praxis, Würselen, Germany; ${ }^{206}$ Universitätsklinikum, Würzburg, Germany; ${ }^{207}$ Hematologisch-Onkologische Schwerpunktpraxis, Würzburg, Germany; ${ }^{208}$ Praxis für Innere Medizin, Zwickau, Germany; ${ }^{209}$ Kantonsspital, Aarau, Switzerland; ${ }^{210}$ Universitätsspital, Basel, Switzerland; ${ }^{211}$ Kantonsspital, Luzern, Switzerland; ${ }^{212}$ Kantonsspital, St. Gallen, Switzerland; ${ }^{213}$ Onkozentrum Klinik im Park, Zürich, Switzerland; ${ }^{214}$ Masaryk University Hospital, Brno, Czech Republic

Funding This work was funded by European LeukemiaNet (ELN) Foundation.

\section{Compliance with ethical standards}

Conflict of interest The authors declare that they have no conflict of interest.

Publisher's note Springer Nature remains neutral with regard to jurisdictional claims in published maps and institutional affiliations.

Open Access This article is licensed under a Creative Commons Attribution 4.0 International License, which permits use, sharing, adaptation, distribution and reproduction in any medium or format, as long as you give appropriate credit to the original author(s) and the source, provide a link to the Creative Commons license, and indicate if changes were made. The images or other third party material in this article are included in the article's Creative Commons license, unless indicated otherwise in a credit line to the material. If material is not included in the article's Creative Commons license and your intended use is not permitted by statutory regulation or exceeds the permitted use, you will need to obtain permission directly from the copyright holder. To view a copy of this license, visit http://creativecommons. org/licenses/by/4.0/.

\section{Appendix A1. Karyotypes of patients with ACA}

\begin{tabular}{|c|c|c|c|c|}
\hline No. & Sex & $\mathrm{Age}^{\mathrm{a}}$ & Interval $^{\mathrm{b}}$ & Karyotype \\
\hline \multicolumn{5}{|c|}{ High-risk ACA in $\mathrm{Ph}+$ cells } \\
\hline \multirow[t]{3}{*}{1} & $\mathrm{~F}$ & 54 & 11 & $46, \mathrm{XX}, \operatorname{inv}(3)(\mathrm{q} 21 \mathrm{q} 26), \mathrm{t}(7 ; 9 ; 22)(\mathrm{q} 31 ; \mathrm{q} 34 ; \mathrm{q} 11)[20]$ \\
\hline & & & 16 & $46, \mathrm{XX}, \operatorname{inv}(3)(\mathrm{q} 21 \mathrm{q} 26), \mathrm{t}(7 ; 9 ; 22)(\mathrm{q} 31 ; \mathrm{q} 34 ; \mathrm{q} 11)[25]$ \\
\hline & & & 20 & $46, \mathrm{XX}, \operatorname{inv}(3)(\mathrm{q} 21 \mathrm{q} 26), \mathrm{t}(7 ; 9 ; 22)(\mathrm{q} 31 ; \mathrm{q} 34 ; \mathrm{q} 11)[25]$ \\
\hline \multirow[t]{2}{*}{2} & $\mathrm{~F}$ & 45 & 28 & $46, \mathrm{XX}, \operatorname{inv}(3)(\mathrm{q} 21 \mathrm{q} 26), \mathrm{t}(9 ; 22)(\mathrm{q} 34 ; \mathrm{q} 11)[19]$ \\
\hline & & & 32 & $46, \mathrm{XX}, \operatorname{inv}(3)(\mathrm{q} 21 \mathrm{q} 26), \mathrm{t}(9 ; 22)(\mathrm{q} 34 ; \mathrm{q} 11)[2]$ \\
\hline 3 & $\mathrm{~F}$ & 61 & 14 & 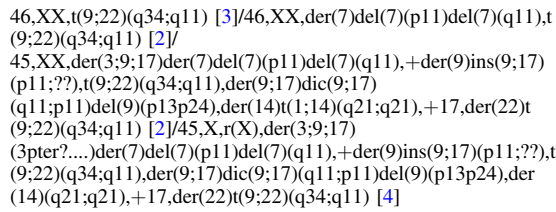 \\
\hline 4 & $\mathrm{M}$ & 42 & 0 & $46, X Y, \operatorname{inv}(3)(\mathrm{p} 13 \mathrm{q} 25), \mathrm{t}(9 ; 22)(\mathrm{q} 34 ; \mathrm{q} 11)[17]$ \\
\hline 5 & $\mathrm{~F}$ & 32 & 12 & $46, \mathrm{XX}, \operatorname{inv}(3)(\mathrm{q} 21 \mathrm{q} 26), \mathrm{t}(9 ; 22)(\mathrm{q} 34 ; \mathrm{q} 11)[15]$ \\
\hline 6 & M & 43 & 8 & $46, X Y, \operatorname{inv}(3)(\mathrm{q} 21 \mathrm{q} 26), \mathrm{t}(9 ; 22)(\mathrm{q} 34 ; \mathrm{q} 11)[24]$ \\
\hline \multirow[t]{3}{*}{7} & $\mathrm{~F}$ & 37 & 6 & $46, \mathrm{XX}, \mathrm{t}(3 ; 21)(\mathrm{q} 26 ; \mathrm{q} 22), \mathrm{t}(9 ; 22)(\mathrm{q} 34 ; \mathrm{q} 11)[15]$ \\
\hline & & & 7 & $46, \mathrm{XX}, \mathrm{t}(3 ; 21)(\mathrm{q} 26 ; \mathrm{q} 22), \mathrm{t}(9 ; 22)(\mathrm{q} 34 ; \mathrm{q} 11)[17]$ \\
\hline & & & 8 & $46, \mathrm{XX}, \mathrm{t}(3 ; 21)(\mathrm{q} 26 ; \mathrm{q} 22), \mathrm{t}(9 ; 22)(\mathrm{q} 34 ; \mathrm{q} 11)[20]$ \\
\hline \multirow[t]{4}{*}{8} & $\mathrm{M}$ & 37 & 11 & $46, \mathrm{XY}, \operatorname{inv}(3)(\mathrm{q} 21 \mathrm{q} 26), \mathrm{t}(9 ; 22)(\mathrm{q} 34 ; \mathrm{q} 11)[9]$ \\
\hline & & & 14 & $46, \mathrm{XY}, \operatorname{inv}(3)(\mathrm{q} 21 \mathrm{q} 26), \mathrm{t}(9 ; 22)(\mathrm{q} 34 ; \mathrm{q} 11)[3]$ \\
\hline & & & 17 & $46, \mathrm{XY}, \operatorname{inv}(3)(\mathrm{q} 21 \mathrm{q} 26), \mathrm{t}(9 ; 22)(\mathrm{q} 34 ; \mathrm{q} 11)[2]$ \\
\hline & & & 24 & $46, \mathrm{XY}, \operatorname{inv}(3)(\mathrm{q} 21 \mathrm{q} 26), \mathrm{t}(9 ; 22)(\mathrm{q} 34 ; \mathrm{q} 11)[3]$ \\
\hline
\end{tabular}

No. Sex Age $^{\mathrm{a}} \quad$ Interval $^{\mathrm{b}}$ Karyotype

\begin{tabular}{|c|c|c|c|c|}
\hline & & & 32 & $46, \mathrm{XY}, \operatorname{inv}(3)(\mathrm{q} 21 \mathrm{q} 26), \mathrm{t}(9 ; 22)(\mathrm{q} 34 ; \mathrm{q} 11)[2]$ \\
\hline & & & 36 & $46, \mathrm{XY}, \operatorname{inv}(3)(\mathrm{q} 21 \mathrm{q} 26), \mathrm{t}(9 ; 22)(\mathrm{q} 34 ; \mathrm{q} 11)[2]$ \\
\hline & & & 44 & $46, \mathrm{XY}, \operatorname{inv}(3)(\mathrm{q} 21 \mathrm{q} 26), \mathrm{t}(9 ; 22)(\mathrm{q} 34 ; \mathrm{q} 11)[6]$ \\
\hline & & & 45 & $46, X Y, \operatorname{inv}(3)(q 21 q 26), t(9 ; 22)(q 34 ; q 11)[20]$ \\
\hline 9 & M & 60 & 6 & $\begin{array}{l}48-49, \mathrm{XY}, \mathrm{t}(5 ; 9)(\mathrm{q} 31 ; \mathrm{q} 22),-7, \operatorname{der}(7) \operatorname{del}(7)(\mathrm{p} 11) \operatorname{del}(7)(\mathrm{q} 11),+8 \\
\operatorname{der}(9) \mathrm{t}(7 ; 9)(\mathrm{q} 11 ; \mathrm{p} 23) \mathrm{t}(9 ; 22)(\mathrm{q} 34 ; \mathrm{q} 11),+19, \operatorname{der}(22) \mathrm{t}(9 ; 22)(\mathrm{q} 34 ; \\
\mathrm{q} 11),+\operatorname{der}(22) \mathrm{t}(9 ; 22)[\mathrm{cp} 12]\end{array}$ \\
\hline 10 & M & 71 & 12 & $\begin{array}{l}46, \mathrm{XY}, \operatorname{der}(5) \mathrm{t}(5 ; 9)(\mathrm{q} 11 ; ?),-7, \operatorname{der}(9) \mathrm{t}(9 ; 22)(\mathrm{q} 34 ; \mathrm{q} 11) \mathrm{t}(9 ; 9)(\mathrm{p} 13 ; ?) \mathrm{t} \\
(7 ; 9)(? ; ?), \\
\operatorname{der}(9) \operatorname{del}(9)(\mathrm{p} 22) \mathrm{t}(9 ; 7)(\mathrm{q} ? ; ?) \mathrm{t}(5 ; 7)(\mathrm{q} ? ; ?), \operatorname{der}(22) \mathrm{t}(9 ; 22)(\mathrm{q} 34 ; \mathrm{q} 11), \\
+\operatorname{der}(22) \mathrm{t}(9 ; 22)(\mathrm{q} 34 ; \mathrm{q} 11)[6]\end{array}$ \\
\hline 11 & M & 45 & 13 & $\begin{array}{l}\text { 46,XY,r(7)(p11q32)del(7)(q11q22),del(9)(p12p24),t(9;22)(q34; } \\
\text { q11) [6] }\end{array}$ \\
\hline 12 & M & 36 & 25 & $\begin{array}{l}43-44, \mathrm{XY},-8, \mathrm{t}(9 ; 22)(\mathrm{q} 34 ; \mathrm{q} 11),-11,-15,-17,-18,-19,-20, \\
-22,+2-3 \operatorname{mar}[\mathrm{cp} 10]\end{array}$ \\
\hline 13 & M & 44 & 3 & $\begin{array}{l}46, \mathrm{XY}, \mathrm{t}(9 ; 22)(\mathrm{q} 34 ; \mathrm{q} 11)[11] / 51, \mathrm{XY},+\mathrm{X}, \operatorname{dup}(6)(\mathrm{p} 22 \mathrm{p} 25),+\operatorname{der}(6) \mathrm{t} \\
(4 ; 6)(\mathrm{q} 24 ; \mathrm{q} 16), \mathrm{t}(9 ; 22)(\mathrm{q} 34 ; \mathrm{q} 11),+14,+21, \\
+\operatorname{der}(22) \mathrm{t}(9 ; 22)(\mathrm{q} 34 ; \mathrm{q} 11)[4] / 51, \mathrm{XY},+\mathrm{X}, \operatorname{der}(4) \mathrm{t}(4 ; 8)(\mathrm{p} 15 ; \mathrm{q} 22), \\
\operatorname{dup}(6)(\mathrm{p} 22 \mathrm{p} 25),+\operatorname{der}(6) \mathrm{t}(4 ; 6)(\mathrm{q} 24 ; \mathrm{q} 16),+14,+21, \\
+\operatorname{der}(22) \mathrm{t}(9 ; 22)(\mathrm{q} 34 ; \mathrm{q} 11)[2]\end{array}$ \\
\hline \multirow[t]{2}{*}{14} & $\mathrm{~F}$ & 68 & 10 & $\begin{array}{l}46, \mathrm{XX}, \mathrm{t}(9 ; 22)(\mathrm{q} 34 ; \mathrm{q} 11)[6] / 46, \mathrm{XX}, \operatorname{inv}(3)(\mathrm{q} 21 \mathrm{q} 26), \mathrm{t}(9 ; 22)(\mathrm{q} 34 ; \\
\mathrm{q} 11)[6]\end{array}$ \\
\hline & & & 13 & $\begin{array}{l}46, \mathrm{XX}, \operatorname{inv}(3)(\mathrm{q} 21 \mathrm{q} 26), \mathrm{t}(9 ; 22)(\mathrm{q} 34 ; \mathrm{q} 11)[2] / 45, \mathrm{XX}, \operatorname{inv}(3) \\
(\mathrm{q} 21 \mathrm{q} 26),-7, \mathrm{t}(9 ; 22)(\mathrm{q} 34 ; \mathrm{q} 11)[10]\end{array}$ \\
\hline \multirow[t]{2}{*}{15} & M & 69 & 9 & $\begin{array}{l}46, \mathrm{XY}, \mathrm{t}(9 ; 22)(\mathrm{q} 34 ; \mathrm{q} 11) / 48, \mathrm{XY},+8, \mathrm{t}(9 ; 22)(\mathrm{q} 34 ; \mathrm{q} 11),+\operatorname{der}(22) \mathrm{t} \\
(9 ; 22)(\mathrm{q} 34 ; \mathrm{q} 11)[3] / \\
50, \mathrm{XY}+8,+8, \mathrm{t}(9 ; 22)(\mathrm{q} 34 ; \mathrm{q} 11),+19,+\operatorname{der}(22) \mathrm{t}(9 ; 22)(\mathrm{q} 34 ; \mathrm{q} 11)[4]\end{array}$ \\
\hline & & & 19 & $45, \mathrm{XY}, \mathrm{t}(3 ; 12)(\mathrm{q} 26 ; \mathrm{q} 24),-7, \mathrm{t}(9 ; 22)(\mathrm{q} 34 ; \mathrm{q} 11)[11]$ \\
\hline \multirow[t]{2}{*}{16} & $\mathrm{~F}$ & 54 & 45 & $46, \mathrm{XX}, \mathrm{t}(3 ; 21)(\mathrm{q} 26 ; \mathrm{q} 22), \mathrm{t}(9 ; 22)(\mathrm{q} 34 ; \mathrm{q} 11)[25]$ \\
\hline & & & 48 & $46, \mathrm{XX}, \mathrm{t}(3 ; 21)(\mathrm{q} 26 ; \mathrm{q} 22), \mathrm{t}(9 ; 22)(\mathrm{q} 34 ; \mathrm{q} 11)[25]$ \\
\hline 17 & M & 64 & 22 & $\begin{array}{l}51, \mathrm{XY},+6,+8,+8, \operatorname{der}(9) \mathrm{t}(9 ; 10)(\mathrm{q} 34 ; \mathrm{q} 22), \operatorname{der}(10) \mathrm{t}(10 ; 15)(\mathrm{q} 22 ; \\
\mathrm{q} 15), \\
+\operatorname{der}(11) \mathrm{t}(11 ; 17)(\mathrm{p} 11.2 ; \mathrm{q} 11.2), \operatorname{der}(15) \mathrm{t}(15 ; 22)(\mathrm{q} 15 ; \mathrm{q} 11.2), \operatorname{der}(22) \\
\mathrm{t}(9 ; 22)(\mathrm{q} 34 ; \mathrm{q} 11.2),+\operatorname{der}(22) \mathrm{t}(9 ; 22)(\mathrm{q} 34 ; \mathrm{q} 11.2)[17]\end{array}$ \\
\hline 18 & M & 24 & 10 & $\begin{array}{l}45, \mathrm{X},-\mathrm{Y}, \mathrm{t}(9 ; 22)(\mathrm{q} 34 ; \mathrm{q} 11)[8] / 46, \mathrm{X},-\mathrm{Y}, \mathrm{t}(9 ; 22)(\mathrm{q} 34 ; \mathrm{q} 11.2),+\mathrm{der} \\
(22) \mathrm{t}(9 ; 22)(\mathrm{q} 34 ; \mathrm{q} 11.2)[4] / \\
47, \mathrm{X},-\mathrm{Y},-7, \mathrm{t}(9 ; 22)(\mathrm{q} 34 ; \mathrm{q} 11.2),+\operatorname{der}(22) \mathrm{t}(9 ; 22)(\mathrm{q} 34 ; \mathrm{q} 11.2), \\
+ \text { mar, }+\mathrm{r}[8]\end{array}$ \\
\hline 19 & M & 61 & 0 & $\begin{array}{l}\text { 46,XY,t(9;22)(q34;q11) [14]/46,XY,der(9)t(9;22)(q34;q11),ider } \\
(22)(\mathrm{q} 10) \mathrm{t}(9 ; 22)(\mathrm{q} 34 ; \mathrm{q} 11)[11]\end{array}$ \\
\hline 20 & M & 51 & 44 & $47, \mathrm{XY}, \mathrm{t}(9 ; 22)(\mathrm{q} 34 ; \mathrm{q} 11),+\operatorname{der}(22) \mathrm{t}(9 ; 22)(\mathrm{q} 34 ; \mathrm{q} 11)[4]$ \\
\hline \multirow[t]{2}{*}{21} & M & 61 & 46 & $\begin{array}{l}\text { 46,XY,t(9;22)(q34;q11),+der(22)idic(9)(q34)t(9;22)(q34;q11), } \\
+\operatorname{der}(22) \mathrm{t}(9 ; 22)(\mathrm{q} 34 ; \mathrm{q} 11) \times 3,+\operatorname{mar}[\mathrm{cp} 20]\end{array}$ \\
\hline & & & 64 & $49, \mathrm{XY}, \mathrm{t}(9 ; 22)(\mathrm{q} 34 ; \mathrm{q} 11),+\operatorname{der}(22) \mathrm{t}(9 ; 22)(\mathrm{q} 34 ; \mathrm{q} 11) \times 3[3]$ \\
\hline 22 & $\mathrm{~F}$ & 60 & 2 & $\begin{array}{l}\text { 46,XX,der(7)t(7;22)(q36;q11)del(7)(q11q22),der(9)t(7;9)(q36; } \\
\mathrm{q} 34), \operatorname{der}(22) \mathrm{t}(9 ; 22)(\mathrm{q} 34 ; \mathrm{q} 11)[21]\end{array}$ \\
\hline 23 & M & 46 & 0 & $\begin{array}{l}47, \mathrm{XY}, \operatorname{der}(9) \mathrm{t}(9 ; 22)(\mathrm{q} 34 ; \mathrm{q} 11), \operatorname{del}(9)(\mathrm{q} 33 \mathrm{q} 34), \operatorname{del}(22)(\mathrm{q} 11 \mathrm{q} 12), \\
+\operatorname{der}(22) \mathrm{t}(9 ; 22)(\mathrm{q} 34 ; \mathrm{q} 11)[25]\end{array}$ \\
\hline 24 & $\mathrm{~F}$ & 59 & 6 & $\begin{array}{l}\text { 46,XX,der(9)t(9;22;15)(q34; } 11 ; \mathrm{q} 26), \operatorname{der}(15) \mathrm{t}(9 ; 22 ; 15),+22, \operatorname{der} \\
(22) \operatorname{idic}(22)(\mathrm{p} 11) \mathrm{t}(9 ; 22)[15]\end{array}$ \\
\hline 25 & M & 34 & 3 & $\begin{array}{l}48, \mathrm{XY},+\mathrm{X}, \operatorname{der}(5) \mathrm{t}(1 ; 5)(\mathrm{q} 21 ; \mathrm{q} 31), \mathrm{t}(9 ; 22 ; 21)(\mathrm{q} 34 ; \mathrm{q} 11 ; \mathrm{q} 22),+ \text { der } \\
(22) \mathrm{t}(9 ; 22)[15]\end{array}$ \\
\hline \multirow[t]{4}{*}{26} & M & 40 & 41 & $47, \mathrm{XY}, \mathrm{t}(9 ; 22)(\mathrm{q} 34 ; \mathrm{q} 11),+\operatorname{der}(22) \mathrm{t}(9 ; 22)(\mathrm{q} 34 ; \mathrm{q} 11)[2]$ \\
\hline & & & 76 & $47, \mathrm{XY}, \mathrm{t}(9 ; 22)(\mathrm{q} 34 ; \mathrm{q} 11),+\operatorname{der}(22) \mathrm{t}(9 ; 22)(\mathrm{q} 34 ; \mathrm{q} 11)[5]$ \\
\hline & & & 78 & $47, \mathrm{XY}, \mathrm{t}(9 ; 22)(\mathrm{q} 34 ; \mathrm{q} 11),+\operatorname{der}(22) \mathrm{t}(9 ; 22)(\mathrm{q} 34 ; \mathrm{q} 11)[8]$ \\
\hline & & & 79 & $47, \mathrm{XY}, \mathrm{t}(9 ; 22)(\mathrm{q} 34 ; \mathrm{q} 11),+\operatorname{der}(22) \mathrm{t}(9 ; 22)(\mathrm{q} 34 ; \mathrm{q} 11)[5]$ \\
\hline 27 & M & 36 & 72 & $\begin{array}{l}46, \mathrm{XY}, \mathrm{t}(9 ; 22)(\mathrm{q} 34 ; \mathrm{q} 11) / 47, \mathrm{XY}, \mathrm{t}(9 ; 22)(\mathrm{q} 34 ; \mathrm{q} 11),+\operatorname{der}(22) \mathrm{t}(9 ; 22) \\
(\mathrm{q} 34 ; \mathrm{q} 11)[3]\end{array}$ \\
\hline 28 & M & 54 & 9 & $47, \mathrm{XY}, \mathrm{t}(9 ; 22)(\mathrm{q} 34 ; \mathrm{q} 11),+\operatorname{der}(22) \mathrm{t}(9 ; 22)(\mathrm{q} 34 ; \mathrm{q} 11)[6]$ \\
\hline \multirow[t]{2}{*}{29} & M & 44 & 29 & $\begin{array}{l}46, \mathrm{XY}, \mathrm{t}(9 ; 22)(\mathrm{q} 34 ; \mathrm{q} 11)[5] / 47, \mathrm{XY}, \mathrm{t}(9 ; 22)(\mathrm{q} 34 ; \mathrm{q} 11),+\operatorname{der}(22) \mathrm{t} \\
(9 ; 22)(\mathrm{q} 34 ; \mathrm{q} 11)[11]\end{array}$ \\
\hline & & & 33 & $\begin{array}{l}46, \mathrm{XY}, \mathrm{t}(9 ; 22)(\mathrm{q} 34 ; \mathrm{q} 11)[3] / 47, \mathrm{XY}, \mathrm{t}(9 ; 22)(\mathrm{q} 34 ; \mathrm{q} 11),+\operatorname{der}(22) \mathrm{t} \\
(9 ; 22)(\mathrm{q} 34 ; \mathrm{q} 11)[9]\end{array}$ \\
\hline 30 & M & 32 & 18 & $\begin{array}{l}\text { 47,XY,t(1;14)(p321;q332),del(9)(p22p24),t(9;22)(q34;q11),+der } \\
(22) \mathrm{t}(9 ; 22)(\mathrm{q} 34 ; \mathrm{q} 11)[9] / \\
46, \mathrm{XY}, \operatorname{del}(9)(\mathrm{p} 22 \mathrm{p} 24), \mathrm{t}(9 ; 22)(\mathrm{q} 34 ; \mathrm{q} 11), \operatorname{del}(12)(\mathrm{p} 11.2 \mathrm{p} 13)[6]\end{array}$ \\
\hline 31 & M & 78 & 13 & $\begin{array}{l}45, \mathrm{X},-\mathrm{Y}, \operatorname{del}(9)(\mathrm{q} 22),+\operatorname{der}(22) \mathrm{t}(9 ; 22)(\mathrm{q} 34 ; \mathrm{q} 11) \mathrm{t}(9 ; 9)(\mathrm{q} 34 ; \mathrm{q} 22) \\
{[13]}\end{array}$ \\
\hline 32 & M & 38 & 27 & $47, \mathrm{XY}, \mathrm{t}(9 ; 22)(\mathrm{q} 34 ; \mathrm{q} 11),+\operatorname{der}(22) \mathrm{t}(9 ; 22)(\mathrm{q} 34 ; \mathrm{q} 11)[14]$ \\
\hline 33 & M & 23 & 0 & $\begin{array}{l}46, \mathrm{XY}, \mathrm{t}(9 ; 22)(\mathrm{q} 34 ; \mathrm{q} 11)[18] / 47, \mathrm{idem},+\operatorname{der}(22) \mathrm{t}(9 ; 22)(\mathrm{q} 34 ; \mathrm{q} 11) \\
{[2]}\end{array}$ \\
\hline 34 & M & 68 & 19 & $\begin{array}{l}46, \mathrm{XX}, \mathrm{t}(9 ; 22)(\mathrm{q} 34 ; \mathrm{q} 11)[5] / 48, \mathrm{XX}, \mathrm{t}(9 ; 22)(\mathrm{q} 34 ; \mathrm{q} 11),+19,+\operatorname{der}(22) \\
\mathrm{t}(9 ; 22)(\mathrm{q} 34 ; \mathrm{q} 11)[8]\end{array}$ \\
\hline \multirow[t]{2}{*}{35} & $\mathrm{~F}$ & 69 & 0 & $\begin{array}{l}46, \mathrm{XX}, \mathrm{t}(9 ; 22)(\mathrm{q} 34 ; \mathrm{q} 11)[8] / 47, \mathrm{idem},+\operatorname{ider}(22)(\mathrm{q} 10) \mathrm{t}(9 ; 22)(\mathrm{q} 34 ; \\
\mathrm{q} 11)[7]\end{array}$ \\
\hline & & & 3 & $\begin{array}{l}46, \mathrm{XX}, \mathrm{t}(9 ; 22)(\mathrm{q} 34 ; \mathrm{q} 11)[7] / 47, \text { idem,ider }(22)(\mathrm{q} 10) \mathrm{t}(9 ; 22)(\mathrm{q} 34 ; \mathrm{q} 11) \\
{[3]}\end{array}$ \\
\hline 36 & $\mathrm{M}$ & 51 & 27 & $\begin{array}{l}46, \mathrm{XY}, \mathrm{t}(9 ; 22)(\mathrm{q} 34 ; \mathrm{q} 11)[14] / 48, \mathrm{idem},+19,+\operatorname{der}(22) \mathrm{t}(9 ; 22)(\mathrm{q} 34 ; \\
\mathrm{q} 11)[2]\end{array}$ \\
\hline
\end{tabular}


No. Sex Age $^{\mathrm{a}}$ Interval $^{\mathrm{b}}$ Karyotype

\begin{tabular}{|c|c|c|c|c|}
\hline \multirow[t]{3}{*}{37} & $\mathrm{~F}$ & 60 & 35 & $45, \mathrm{XX},-7, \mathrm{t}(9 ; 22)(\mathrm{q} 34 ; \mathrm{q} 11)[7]$ \\
\hline & & & 41 & $\begin{array}{l}46, \mathrm{XX}, \mathrm{r}(7)(\mathrm{p} 13 \mathrm{q} 11), \mathrm{t}(9 ; 22)(\mathrm{q} 34 ; \mathrm{q} 11)[9] / 45, \mathrm{XX},-7, \mathrm{t}(9 ; 22)(\mathrm{q} 34 ; \\
\mathrm{q} 11)[4]\end{array}$ \\
\hline & & & 44 & $\begin{array}{l}46, \mathrm{XX}, \mathrm{r}(7)(\mathrm{p} 13 \mathrm{q} 11), \mathrm{t}(9 ; 22)(\mathrm{q} 34 ; \mathrm{q} 11)[7] / 45, \mathrm{XX},-7, \mathrm{t}(9 ; 22)(\mathrm{q} 34 ; \\
\mathrm{q} 11)[2]\end{array}$ \\
\hline \multirow[t]{2}{*}{38} & M & 39 & 12 & $\begin{array}{l}46, \mathrm{XY}, \mathrm{t}(9 ; 22)(\mathrm{q} 34 ; \mathrm{q} 11)[7] / 47, \mathrm{XY},+8, \mathrm{t}(9 ; 22)(\mathrm{q} 34 ; \mathrm{q} 11)[2] / 48, \\
\mathrm{XY},+8, \mathrm{t}(9 ; 22)(\mathrm{q} 34 ; \mathrm{q} 11),+\operatorname{der}(22) \mathrm{t}(9 ; 22)(\mathrm{q} 34 ; \mathrm{q} 11)[3]\end{array}$ \\
\hline & & & 88 & $\begin{array}{l}46, \mathrm{XY}, \mathrm{t}(9 ; 22)(\mathrm{q} 34 ; \mathrm{q} 11) / 47, \mathrm{XY},+8, \mathrm{t}(9 ; 22)(\mathrm{q} 34 ; \mathrm{q} 11) / 48, \mathrm{XY},+8, \\
\mathrm{t}(9 ; 22)(\mathrm{q} 34 ; \mathrm{q} 11),+\operatorname{der}(22) \mathrm{t}(9 ; 22)(\mathrm{q} 34 ; \mathrm{q} 11)[16]\end{array}$ \\
\hline 39 & $\mathrm{~F}$ & 58 & 7 & $\begin{array}{l}55, \mathrm{XX},+\mathrm{X},+5,+6,+7,+8, \mathrm{t}(9 ; 22)(\mathrm{q} 34 ; \mathrm{q} 11),+14,+19,+22,+\mathrm{der} \\
(22) \mathrm{t}(9 ; 22)(\mathrm{q} 34 ; \mathrm{q} 11)[\mathrm{cp} 5]\end{array}$ \\
\hline 40 & M & 38 & 15 & $47, \mathrm{XY}, \mathrm{t}(9 ; 22)(\mathrm{q} 34 ; \mathrm{q} 11),+8[2]$ \\
\hline 41 & M & 39 & 0 & $\begin{array}{l}47, \mathrm{XY},+8, \mathrm{t}(9 ; 22)(\mathrm{q} 34 ; \mathrm{q} 11)[2] / 47, \mathrm{XY},+8, \mathrm{t}(9 ; 22)(\mathrm{q} 34 ; \mathrm{q} 11), \mathrm{i}(17) \\
(\mathrm{q} 10)[2] / 48, \mathrm{XY},+8, \mathrm{t}(9 ; 22)(\mathrm{q} 34 ; \mathrm{q} 11), \mathrm{i}(17)(\mathrm{q} 10),+22 \\
\operatorname{del}(22) \mathrm{q} 11)[10]\end{array}$ \\
\hline 42 & M & 64 & 10 & $\begin{array}{l}46, \mathrm{XY}, \mathrm{t}(9 ; 22)(\mathrm{q} 34 ; \mathrm{q} 11)[16] / 50, \mathrm{XY},+8,+12,+18,+21, \mathrm{t}(9 ; 22) \\
(\mathrm{q} 34 ; \mathrm{q} 11)[3]\end{array}$ \\
\hline \multirow[t]{2}{*}{43} & M & 34 & 5 & $46, \mathrm{XY}, \mathrm{t}(9 ; 22)(\mathrm{q} 34 ; \mathrm{q} 11)[13] / 47, \mathrm{XY},+8, \mathrm{t}(9 ; 22)(\mathrm{q} 34 ; \mathrm{q} 11)[5]$ \\
\hline & & & 117 & $46, \mathrm{XY}, \mathrm{t}(9 ; 22)(\mathrm{q} 34 ; \mathrm{q} 11)[9] / 47, \mathrm{XY},+8, \mathrm{t}(9 ; 22)(\mathrm{q} 34 ; \mathrm{q} 11)[6]$ \\
\hline \multirow[t]{2}{*}{44} & $\mathrm{~F}$ & 54 & 73 & $46, \mathrm{XX}, \mathrm{t}(9 ; 22)(\mathrm{q} 34 ; \mathrm{q} 11)[2] / 47, \mathrm{XX},+8, \mathrm{t}(9 ; 22)(\mathrm{q} 34 ; \mathrm{q} 11)[12]$ \\
\hline & & & 81 & $47, \mathrm{XX},+\operatorname{der}(8), \mathrm{t}(1 ; 8)(\mathrm{q} 22 ; \mathrm{p} 22), \mathrm{t}(9 ; 22)(\mathrm{q} 34 ; \mathrm{q} 11)[2]$ \\
\hline 45 & $\mathrm{~F}$ & 42 & 51 & $46, \mathrm{XX}, \mathrm{t}(9 ; 22)(\mathrm{q} 34 ; \mathrm{q} 11)[17] / 47, \mathrm{XX},+8, \mathrm{t}(9 ; 22)(\mathrm{q} 34 ; \mathrm{q} 11)[3]$ \\
\hline \multirow[t]{2}{*}{46} & M & 72 & 0 & $47, \mathrm{XY},+8, \mathrm{t}(9 ; 22)(\mathrm{q} 34 ; \mathrm{q} 11)[20]$ \\
\hline & & & 7 & $46, \mathrm{XY}, \mathrm{t}(9 ; 22)(\mathrm{q} 34 ; \mathrm{q} 11)[6] / 47, \mathrm{XY},+8, \mathrm{t}(9 ; 22)(\mathrm{q} 34 ; \mathrm{q} 11)[18]$ \\
\hline 47 & M & 40 & 0 & $\begin{array}{l}47, \mathrm{XY},+8, \mathrm{t}(9 ; 22)(\mathrm{q} 34 ; \mathrm{q} 11)[17] / 49, \mathrm{XY},+8, \mathrm{t}(9 ; 22)(\mathrm{q} 34 ; \mathrm{q} 11),+19, \\
+20[7]\end{array}$ \\
\hline 48 & M & 25 & 0 & $46, \mathrm{XY}, \mathrm{t}(9 ; 22)(\mathrm{q} 34 ; \mathrm{q} 11)[22] / 47, \mathrm{XY},+8, \mathrm{t}(9 ; 22)(\mathrm{q} 34 ; \mathrm{q} 11)[3]$ \\
\hline \multirow[t]{5}{*}{49} & $\mathrm{~F}$ & 24 & 23 & $46, \mathrm{XX}, \mathrm{t}(9 ; 22)(\mathrm{q} 34 ; \mathrm{q} 11)[4] / 47, \mathrm{XX},+8, \mathrm{t}(9 ; 22)(\mathrm{q} 34 ; \mathrm{q} 11)[4]$ \\
\hline & & & 29 & $46, \mathrm{XX}, \mathrm{t}(9 ; 22)(\mathrm{q} 34 ; \mathrm{q} 11)[11] / 47, \mathrm{XX},+8, \mathrm{t}(9 ; 22)(\mathrm{q} 34 ; \mathrm{q} 11)[2]$ \\
\hline & & & 36 & $46, \mathrm{XX}, \mathrm{t}(9 ; 22)(\mathrm{q} 34 ; \mathrm{q} 11)[3] / 47, \mathrm{XX},+8, \mathrm{t}(9 ; 22)(\mathrm{q} 34 ; \mathrm{q} 11)[18]$ \\
\hline & & & 40 & $47, \mathrm{XX},+8, \mathrm{t}(9 ; 22)(\mathrm{q} 34 ; \mathrm{q} 11)[20]$ \\
\hline & & & 44 & $47, \mathrm{XX},+8, \mathrm{t}(9 ; 22)(\mathrm{q} 34 ; \mathrm{q} 11)[5]$ \\
\hline 50 & M & 31 & 0 & $\begin{array}{l}46, \mathrm{XY}, \mathrm{t}(9 ; 22 ; 10)(\mathrm{q} 34 ; \mathrm{q} 11 ; \mathrm{p} 15)[13] / 55, \mathrm{XY},+3,+8, \mathrm{t}(9 ; 22 ; 10) \\
(\mathrm{q} 34 ; \mathrm{q} 11 ; \mathrm{p} 15),+12,+13,+14,+18,+19,+21,+\operatorname{der}(22) \\
\mathrm{t}(9 ; 22(\mathrm{q} 34 ; \mathrm{q} 11)[7]\end{array}$ \\
\hline \multirow[t]{2}{*}{51} & M & 28 & 0 & $\begin{array}{l}46, \mathrm{XY}, \mathrm{t}(9 ; 22)(\mathrm{q} 34 ; \mathrm{q} 11)[10] / 47, \mathrm{XY}, \mathrm{t}(9 ; 22)(\mathrm{q} 34 ; \mathrm{q} 11),+\operatorname{der}(22) \mathrm{t} \\
(9 ; 22)(\mathrm{q} 34: \mathrm{q} 11)[10]\end{array}$ \\
\hline & & & 3 & $\begin{array}{l}46, \mathrm{XY}, \mathrm{t}(9 ; 22)(\mathrm{q} 34 ; \mathrm{q} 11) / 47, \mathrm{XY}, \mathrm{t}(9 ; 22)(\mathrm{q} 34 ; \mathrm{q} 11),+\operatorname{der}(22) \mathrm{t}(9 ; 22) \\
(\mathrm{q} 34: \mathrm{q} 11)[20]\end{array}$ \\
\hline \multirow[t]{2}{*}{52} & M & 55 & 0 & $\begin{array}{l}46, \mathrm{XY}, \mathrm{t}(9 ; 22)(\mathrm{q} 34 ; \mathrm{q} 11)[7] / 49, \mathrm{XY},+8,+10, \mathrm{t}(9 ; 22)(\mathrm{q} 34 ; \mathrm{q} 11),+\mathrm{der} \\
(22) \mathrm{t}(9 ; 22)(\mathrm{q} 34: \mathrm{q} 11)[13]\end{array}$ \\
\hline & & & 6 & $\begin{array}{l}46, \mathrm{XY}, \mathrm{t}(9 ; 22)(\mathrm{q} 34 ; \mathrm{q} 11)[3] / 49, \mathrm{XY},+8,+10, \mathrm{t}(9 ; 22)(\mathrm{q} 34 ; \mathrm{q} 11),+\mathrm{der} \\
(22) \mathrm{t}(9 ; 22)(\mathrm{q} 34: \mathrm{q} 11)[12]\end{array}$ \\
\hline \multirow[t]{2}{*}{53} & $\mathrm{~F}$ & 68 & 0 & $48, \mathrm{XX},+8, \mathrm{t}(9 ; 18)(\mathrm{q} 34 ; \mathrm{q} 21),+\operatorname{der}(22) \operatorname{ins}(22 ; 9)(\mathrm{q} 11 ; 34 \mathrm{q} 34)[5]$ \\
\hline & & & 6 & $48, \mathrm{XX},+8, \mathrm{t}(9 ; 18)(\mathrm{q} 34 ; \mathrm{q} 21),+\operatorname{der}(22) \operatorname{ins}(22 ; 9)(\mathrm{q} 11 ; 34 \mathrm{q} 34)[4]$ \\
\hline 54 & M & 38 & 0 & $\begin{array}{l}47, \mathrm{XY},+8, \mathrm{t}(9 ; 22)(\mathrm{q} 34 ; \mathrm{q} 11)[3] / 48, \mathrm{XY},+8, \mathrm{t}(9 ; 22)(\mathrm{q} 34 ; \mathrm{q} 11),+ \text { der } \\
(22) \mathrm{t}(9 ; 22)(\mathrm{q} 34 ; \mathrm{q} 11)[11]\end{array}$ \\
\hline 55 & M & 53 & 0 & $50, \mathrm{XY},+8,+8, \mathrm{i}(17)(\mathrm{q} 10),+19,+\operatorname{der}(22) \mathrm{t}(9 ; 22)(\mathrm{q} 34 ; \mathrm{q} 11)[6]$ \\
\hline 56 & M & 28 & 10 & $\begin{array}{l}45, \mathrm{XY}, \mathrm{t}(8 ; 21)(\mathrm{q} 22 ; \mathrm{q} 22), \mathrm{t}(9 ; 22)(\mathrm{q} 34 ; \mathrm{q} 11),-11 / 93, \mathrm{XXYY},+8,+8, \mathrm{t} \\
(8 ; 21)(\mathrm{q} 22 ; \mathrm{q} 22), \mathrm{t}(9 ; 22)(\mathrm{q} 34 ; \mathrm{q} 11),-11[8]\end{array}$ \\
\hline \multirow[t]{2}{*}{57} & M & 70 & 19 & $46, \mathrm{XY}, \mathrm{t}(9 ; 22)(\mathrm{q} 34 ; \mathrm{q} 11)[19] / 47, \mathrm{XY},+8, \mathrm{t}(9 ; 22)(\mathrm{q} 34 ; \mathrm{q} 11)[4]$ \\
\hline & & & 64 & $46, \mathrm{XY}, \mathrm{t}(9 ; 22)(\mathrm{q} 34 ; \mathrm{q} 11)[4] / 47, \mathrm{XY},+8, \mathrm{t}(9 ; 22)(\mathrm{q} 34 ; \mathrm{q} 11)[16]$ \\
\hline 58 & M & 55 & 0 & $\begin{array}{l}46, \mathrm{XY}, \mathrm{t}(1 ; 12)(\mathrm{p} 34 ; \mathrm{q} 24), \mathrm{t}(1 ; 9 ; 22)(\mathrm{p} 36 ; \mathrm{q} 34 ; \mathrm{q} 11)[21] / 48, \mathrm{idem},+8 \\
+9[2]\end{array}$ \\
\hline \multirow[t]{4}{*}{59} & M & 46 & 52 & $46, \mathrm{XY}, \mathrm{t}(9 ; 22)(\mathrm{q} 34 ; \mathrm{q} 11)[8] / 47, \mathrm{XY},+8, \mathrm{t}(9 ; 22)(\mathrm{q} 34 ; \mathrm{q} 11)[7]$ \\
\hline & & & 72 & $46, \mathrm{XY}, \mathrm{t}(9 ; 22)(\mathrm{q} 34 ; \mathrm{q} 11)[19] / 47, \mathrm{XY},+8, \mathrm{t}(9 ; 22)(\mathrm{q} 34 ; \mathrm{q} 11)[4]$ \\
\hline & & & 80 & $47, \mathrm{XY},+8, \mathrm{t}(9 ; 22)(\mathrm{q} 34 ; \mathrm{q} 11)[4]$ \\
\hline & & & 86 & $46, \mathrm{XY}, \mathrm{t}(9 ; 22)(\mathrm{q} 34 ; \mathrm{q} 11)[4] / 47, \mathrm{XY},+8, \mathrm{t}(9 ; 22)(\mathrm{q} 34 ; \mathrm{q} 11)[13]$ \\
\hline \multirow[t]{5}{*}{60} & M & 64 & 42 & $46, \mathrm{XY}, \mathrm{t}(9 ; 22)(\mathrm{q} 34 ; \mathrm{q} 11)[17] / 47, \mathrm{XY},+8, \mathrm{t}(9 ; 22)(\mathrm{q} 34 ; \mathrm{q} 11)[2]$ \\
\hline & & & 53 & $46, \mathrm{XY}, \mathrm{t}(9 ; 22)(\mathrm{q} 34 ; \mathrm{q} 11)[17] / 47, \mathrm{XY},+8, \mathrm{t}(9 ; 22)(\mathrm{q} 34 ; \mathrm{q} 11)[2]$ \\
\hline & & & 57 & $46, \mathrm{XY}, \mathrm{t}(9 ; 22)(\mathrm{q} 34 ; \mathrm{q} 11)[5] / 47, \mathrm{XY},+8, \mathrm{t}(9 ; 22)(\mathrm{q} 34 ; \mathrm{q} 11)[2]$ \\
\hline & & & 65 & $46, \mathrm{XY}, \mathrm{t}(9 ; 22)(\mathrm{q} 34 ; \mathrm{q} 11)[4] / 47, \mathrm{XY},+8, \mathrm{t}(9 ; 22)(\mathrm{q} 34 ; \mathrm{q} 11)[2]$ \\
\hline & & & 69 & $47, \mathrm{XY},+8, \mathrm{t}(9 ; 22)(\mathrm{q} 34 ; \mathrm{q} 11)[2] / 46, \mathrm{XY}, \operatorname{del}(7)(\mathrm{q} 11 ; \mathrm{q} 22)[6]$ \\
\hline 61 & M & 57 & 0 & $48, \mathrm{XY},+8, \mathrm{t}(9 ; 22)(\mathrm{q} 34 ; \mathrm{q} 11),+19[25]$ \\
\hline 62 & M & 50 & 76 & $\begin{array}{l}46, \mathrm{XY}, \mathrm{t}(9 ; 22)(\mathrm{q} 34 ; \mathrm{q} 11) / 47, \mathrm{XY},+8, \mathrm{t}(9 ; 22)(\mathrm{q} 34 ; \mathrm{q} 11), \operatorname{idic}(17)(\mathrm{p} 11) \\
{[24]}\end{array}$ \\
\hline 63 & M & 46 & 102 & $47, \mathrm{XY},+8, \mathrm{t}(9 ; 22)(\mathrm{q} 34 ; \mathrm{q} 11), \mathrm{i}(17)(\mathrm{q} 10)[6]$ \\
\hline 64 & M & 41 & 0 & $\begin{array}{l}46, \mathrm{XY}, \mathrm{t}(9 ; 22)(\mathrm{q} 34 ; \mathrm{q} 11)[10] / 44, \mathrm{XY}, \mathrm{t}(9 ; 22)(\mathrm{q} 34 ; \mathrm{q} 11),-14, \mathrm{i}(17) \\
(\mathrm{q} 10),-18[15]\end{array}$ \\
\hline 65 & $\mathrm{~F}$ & 62 & 10 & $\begin{array}{l}46, \mathrm{XX}, \mathrm{t}(1 ; 9 ; 22)(\mathrm{p} 36 ; \mathrm{q} 34 ; \mathrm{q} 11)[8] / 47, \mathrm{XX}, \mathrm{t}(1 ; 9 ; 22)(\mathrm{p} 36 ; \mathrm{q} 34 ; \mathrm{q} 11) \\
+8[2]\end{array}$ \\
\hline 66 & $\mathrm{~F}$ & 76 & 8 & $47, \mathrm{XX},+8, \mathrm{t}(9 ; 22)(\mathrm{q} 34 ; \mathrm{q} 11)[3]$ \\
\hline 67 & M & 44 & 20 & $46, \mathrm{XY}, \mathrm{t}(3 ; 21)(\mathrm{q} 26 ; \mathrm{q} 22), \mathrm{t}(9 ; 22)(\mathrm{q} 34 ; \mathrm{q} 11)[16] / 46, \mathrm{XY}[4]$ \\
\hline
\end{tabular}

No. Sex Age $^{\mathrm{a}}$ Interval $^{\mathrm{b}}$ Karyotype

\begin{tabular}{|c|c|c|c|c|}
\hline & & & 34 & $\begin{array}{l}49, \mathrm{XY}, \mathrm{t}(3 ; 21)(\mathrm{q} 26 ; \mathrm{q} 22),+8, \mathrm{t}(9 ; 22)(\mathrm{q} 34 ; \mathrm{q} 11),+12,+\operatorname{der}(22) \mathrm{t}(9 ; 22) \\
(\mathrm{q} 34 ; \mathrm{q} 11)[4] / 46, \mathrm{XY}[19]\end{array}$ \\
\hline \multirow[t]{3}{*}{68} & $\mathrm{~F}$ & 52 & 0 & $47, \mathrm{XX},+8, \mathrm{t}(9 ; 22)(\mathrm{q} 34 ; \mathrm{q} 11), \mathrm{i}(17)(\mathrm{q} 10)[10]$ \\
\hline & & & 3 & $47, \mathrm{XX},+8, \mathrm{t}(9 ; 22)(\mathrm{q} 34 ; \mathrm{q} 11), \operatorname{idic}(17)(\mathrm{p} 12)[4] / 46, \mathrm{XX}[21]$ \\
\hline & & & 8 & $\begin{array}{l}50, \mathrm{XX},+8,+8,+8, \mathrm{t}(9 ; 22)(\mathrm{q} 34 ; \mathrm{q} 11), \operatorname{idic}(17)(\mathrm{p} 12),+19[7] / 46, \mathrm{XX} \\
{[20]}\end{array}$ \\
\hline 69 & $\mathrm{~F}$ & 56 & 0 & $46, \mathrm{XX}, \mathrm{t}(9 ; 22)(\mathrm{q} 34 ; \mathrm{q} 11)[21] / 47, \mathrm{XX},+8, \mathrm{t}(9 ; 22)(\mathrm{q} 34 ; \mathrm{q} 11)[2]$ \\
\hline 70 & M & 48 & 0 & $46, \mathrm{XY}, \mathrm{t}(9 ; 22)(\mathrm{q} 34 ; \mathrm{q} 11)[6] / 47, \mathrm{XY},+8, \mathrm{t}(9 ; 22)(\mathrm{q} 34 ; \mathrm{q} 11)[12]$ \\
\hline 71 & M & 51 & 0 & $\begin{array}{l}46, \mathrm{XY}, \mathrm{t}(9 ; 22)((\mathrm{q} 34 ; \mathrm{q} 11)[7] / 47, \mathrm{XY},+8, \mathrm{t}(9 ; 22)(\mathrm{q} 34 ; \mathrm{q} 11), \mathrm{i}(17) \\
(\mathrm{q} 10)[18]\end{array}$ \\
\hline 72 & $\mathrm{~F}$ & 75 & 24 & $47, \mathrm{XX}, \mathrm{t}(9 ; 22)(\mathrm{q} 34 ; \mathrm{q} 11),+21[4]$ \\
\hline 73 & $\mathrm{~F}$ & 39 & 0 & $\begin{array}{l}46, \mathrm{XX}, \mathrm{t}(9 ; 22)(\mathrm{q} 34 ; \mathrm{q} 11)[3] / 46, \text { idem,t(20;21)(q10;q10)/47,idem,t } \\
(20 ; 21)(\mathrm{q} 10 ; \mathrm{q} 10),+21[11]\end{array}$ \\
\hline \multirow[t]{2}{*}{74} & M & 42 & 19 & $47, \mathrm{XY}, \mathrm{t}(9 ; 22)(\mathrm{q} 34 ; \mathrm{q} 11),+17[20]$ \\
\hline & & & 21 & $47, \mathrm{XY}, \mathrm{t}(9 ; 22)(\mathrm{q} 34 ; \mathrm{q} 11),+17[10]$ \\
\hline 75 & $\mathrm{~F}$ & 62 & 11 & $46, \mathrm{XX}, \mathrm{t}(9 ; 11)(\mathrm{p} 21-22 ; \mathrm{q} 23), \mathrm{t}(9 ; 22)(\mathrm{q} 34 ; \mathrm{q} 11)[25]$ \\
\hline 76 & M & 51 & 38 & $\begin{array}{l}\text { 46,XY,t(9;22)(q34;q11),inv(16)(p13q22), }+\operatorname{der}(22) \mathrm{t}(9 ; 22)(\mathrm{q} 34 ; \\
\mathrm{q} 11)[3]\end{array}$ \\
\hline 77 & $\mathrm{~F}$ & 59 & 32 & $48, \mathrm{XX}, \mathrm{t}(9 ; 15 ; 22)(\mathrm{q} 34 ; \mathrm{q} 26 ; \mathrm{q} 11),+8,+19[3]$ \\
\hline 78 & $\mathrm{~F}$ & 51 & 7 & $45, \mathrm{XX}, \operatorname{der}(7 ; 9)(\mathrm{q} 10 ; \mathrm{q} 10) \mathrm{t}(9 ; 22)(\mathrm{q} 34 ; \mathrm{q} 11)[8]$ \\
\hline 79 & M & 24 & 8 & $\begin{array}{l}46, \mathrm{XY}, \operatorname{der}(9) \mathrm{t}(9 ; 22)(\mathrm{q} 34 ; \mathrm{q} 11), \operatorname{der}(19) \mathrm{t}(9 ; 19)(\mathrm{q} 34 ; \mathrm{p} 13) ; \operatorname{der}(22) \mathrm{t} \\
(9 ; 22)(\mathrm{q} 34 ; \mathrm{q} 11) \\
\mathrm{t}(9 ; 19)(\mathrm{q} 34, \mathrm{p} 13)[2]\end{array}$ \\
\hline 80 & M & 53 & 0 & $\begin{array}{l}46, \mathrm{XY}, \operatorname{der}(9) \mathrm{t}(9 ; 22)(\mathrm{q} 34 ; \mathrm{q} 11) \text { idicder(22)(q11)t(9;22)(q34;q11), } \\
\operatorname{idicder}(22)(\mathrm{q} 11) \mathrm{t}(9 ; 22)(\mathrm{q} 34 ; \mathrm{q} 11)[3]\end{array}$ \\
\hline 81 & M & 55 & 0 & $\begin{array}{l}46, \mathrm{XY}, \operatorname{der}(7) \mathrm{t}(7 ; 9)(\mathrm{q} 11.2 ; \mathrm{q} 34), \operatorname{der}(9) \mathrm{t}(9 ; 22)(\mathrm{q} 34 ; \mathrm{q} 11.2), \operatorname{der}(22) \mathrm{t} \\
(9 ; 22)(\mathrm{q} 34 ; \mathrm{q} 11.2) \\
\mathrm{t}(7 ; 9)(\mathrm{q} 11.2 \mathrm{q} 34)[13]\end{array}$ \\
\hline 82 & M & 40 & 0 & $47, \mathrm{XY},+8, \mathrm{t}(9 ; 22)(\mathrm{q} 34 ; \mathrm{q} 11)[16]$ \\
\hline 83 & $\mathrm{~F}$ & 68 & 13 & $46, \mathrm{XX}, \mathrm{t}(3 ; 11)(\mathrm{q} 26 ; \mathrm{q} 23), \mathrm{t}(9 ; 22)(\mathrm{q} 34 ; \mathrm{q} 11)[20]$ \\
\hline 84 & $\mathrm{~F}$ & 54 & 45 & $46, \mathrm{XX}, \mathrm{t}(3 ; 21)(\mathrm{q} 26 ; \mathrm{q} 22), \mathrm{t}(9 ; 22)(\mathrm{q} 34 ; \mathrm{q} 11)[25]$ \\
\hline 85 & & 42 & 40 & $\begin{array}{l}\text { 47,XY,der(8)t(8;9)(p21;p13),+der(8)t(8;9)(p21;p13), del(9) } \\
(\mathrm{p} 13 \mathrm{p} 24), \\
\operatorname{der}(9) \mathrm{t}(8 ; 9)(\mathrm{p} 21 ; \mathrm{p} 11) \mathrm{t}(9 ; 10)(\mathrm{q} 34 ; \mathrm{q} 24), \operatorname{der}(10) \mathrm{t}(10 ; 22)(\mathrm{q} 24 ; \mathrm{q} 11) \\
\mathrm{t}(14 ; 21)(\mathrm{q} 22 ; \mathrm{q} 21), \operatorname{der}(22) \mathrm{t}(9 ; 22)(\mathrm{q} 34 ; \mathrm{q} 11)[10]\end{array}$ \\
\hline 86 & M & 60 & 22 & $46, \mathrm{XY}, \operatorname{inv}(7)(\mathrm{p} 22 \mathrm{q} 32),+8, \mathrm{t}(9 ; 22)(\mathrm{q} 34 ; \mathrm{q} 11)[20]$ \\
\hline \multirow[t]{4}{*}{87} & M & 44 & 0 & $\begin{array}{l}\text { 46,XY,der(9)t(9;10)(q22;q23)t(10;22)(q25;q11),der(10)t(9;10) } \\
(\mathrm{q} 22 ; \mathrm{q} 23) \mathrm{t}(9 ; 15)(\mathrm{q} 34 ; \mathrm{q} 21), \operatorname{der}(15) \mathrm{t}(10 ; 15)(\mathrm{q} 26 ; \mathrm{q} 15) \\
\mathrm{t}(10 ; 22)(\mathrm{q} 25 ; \mathrm{q} 11), \operatorname{der}(22) \mathrm{t}(9 ; 22)(\mathrm{q} 34 ; \mathrm{q} 11)[21]\end{array}$ \\
\hline & & & 4 & $\begin{array}{l}\text { 46,XY,der(9)t(9;10)(q22;q23)t(10;22)(q25;q11),der(10)t(9;10) } \\
(\mathrm{q} 22 ; \mathrm{q} 23) \mathrm{t}(9 ; 15)(\mathrm{q} 34 ; \mathrm{q} 21), \operatorname{der}(15) \mathrm{t}(10 ; 15)(\mathrm{q} 26 ; \mathrm{q} 15) \\
\mathrm{t}(10 ; 22)(\mathrm{q} 25 ; \mathrm{q} 11), \operatorname{der}(22) \mathrm{t}(9 ; 22)(\mathrm{q} 34 ; \mathrm{q} 11)[8]\end{array}$ \\
\hline & & & 7 & $\begin{array}{l}\text { 46,XY,der(9)t(9;10)(q22;q23)t(10;22)(q25;q11),der(10)t(9;10) } \\
(\mathrm{q} 22 ; \mathrm{q} 23) \mathrm{t}(9 ; 15)(\mathrm{q} 34 ; \mathrm{q} 21), \operatorname{der}(15) \mathrm{t}(10 ; 15)(\mathrm{q} 26 ; \mathrm{q} 15) \\
\mathrm{t}(10 ; 22)(\mathrm{q} 25 ; \mathrm{q} 11), \operatorname{der}(22) \mathrm{t}(9 ; 22)(\mathrm{q} 34 ; \mathrm{q} 11)[3]\end{array}$ \\
\hline & & & 10 & $\begin{array}{l}46, \mathrm{XY}, \operatorname{der}(9) \mathrm{t}(9 ; 10)(\mathrm{q} 22 ; \mathrm{q} 23) \mathrm{t}(10 ; 22)(\mathrm{q} 25 ; \mathrm{q} 11), \operatorname{der}(10) \mathrm{t}(9 ; 10) \\
(\mathrm{q} 22 ; \mathrm{q} 23) \mathrm{t}(9 ; 15)(\mathrm{q} 34 ; \mathrm{q} 21), \operatorname{der}(15) \mathrm{t}(10 ; 15)(\mathrm{q} 26 ; \mathrm{q} 15) \\
\mathrm{t}(10 ; 22)(\mathrm{q} 25 ; \mathrm{q} 11), \operatorname{der}(22) \mathrm{t}(9 ; 22)(\mathrm{q} 34 ; \mathrm{q} 11)[3]\end{array}$ \\
\hline 88 & $\mathrm{~F}$ & 38 & 0 & $\begin{array}{l}\text { 46,XX,del(1)(q21),der(9)t(9;22)(q34;q11)t(1;22)(q44;q11), der(22) } \\
\mathrm{t}(9 ; 22)(\mathrm{q} 34 ; \mathrm{q} 11) \mathrm{t}(1 ; 9)(\mathrm{q} 21 ; \mathrm{q} 34)[20]\end{array}$ \\
\hline 89 & $\mathrm{~F}$ & 66 & 0 & $\begin{array}{l}46, \mathrm{XX}, \operatorname{del}(1)(\mathrm{q} 32), \operatorname{der}(9) \mathrm{t}(1 ; 9)(\mathrm{q} 32 ; \mathrm{q} 34) \mathrm{t}(1 ; 22)(\mathrm{q} 44 ; \mathrm{q} 11), \operatorname{der}(22) \mathrm{t} \\
(9 ; 22)(\mathrm{q} 34 ; \mathrm{q} 11)[20]\end{array}$ \\
\hline 90 & M & 55 & 0 & $\begin{array}{l}46, \mathrm{XY}, \mathrm{t}(7 ; 11), \operatorname{del}(7 \mathrm{q}), \operatorname{der}(9) \mathrm{t}(9 ; 22)(\mathrm{q} 34 ; \mathrm{q} 11), \operatorname{der}(11), \operatorname{del}(16 \mathrm{q}), \operatorname{der} \\
(17), \operatorname{der}(22) \mathrm{t}(9 ; 22)(\mathrm{q} 34 ; \mathrm{q} 11)[10]\end{array}$ \\
\hline \multirow[t]{3}{*}{91} & $\mathrm{~F}$ & 47 & 0 & $\begin{array}{l}\text { 46,XX,t(9;22)(q34;q11) [2]/46,XX,der(7;11)ins(7;11)(p14; } \\
\text { p11q25)t(7;11)(p22;p11),t(9;22)(q34;q11) [13] }\end{array}$ \\
\hline & & & 3 & $\begin{array}{l}\text { 46,XX,t(9;22)(q34;q11) [5]/45,XX,der(7;11)ins(7;11)(p14; } \\
\text { p11q25)t(7;11)(p22;p11),t(9;22)(q34;q11) [14]/ } \\
\text { 46,XX,t(9;22)(q34;q11),del(11)(p13) [2]/46,XX,del(4)(q31),der } \\
(11) \mathrm{t}(4 ; 11)(\mathrm{q} ? ; \mathrm{p} 13) \mathrm{t}(11 ; 13)(\mathrm{q} 21 ; \mathrm{q} 14), \\
\operatorname{der}(12) \mathrm{t}(11 ; 12)(\mathrm{p} 13 ; \mathrm{q} 24), \operatorname{der}(13) \mathrm{t}(11 ; 13)(\mathrm{q} 21 ; \mathrm{q} 14)[2]\end{array}$ \\
\hline & & & 6 & $\begin{array}{l}\text { 46,XX,t(9;22)(q34;q11) [2]/45,XX,der(7;11)ins(7;11)(p14; } \\
\text { p11q25)t(7;11)(p22;p11),t(9;22)(q34;q11) [9] }\end{array}$ \\
\hline \multicolumn{5}{|c|}{ Low-risk ACA in $\mathrm{Ph}+$ cells } \\
\hline \multirow[t]{4}{*}{92} & M & 59 & 0 & $46, \mathrm{XY}, \mathrm{t}(9 ; 22)(\mathrm{q} 34 ; \mathrm{q} 11), \operatorname{del}(15)(\mathrm{q} 22), \operatorname{add}(17)(\mathrm{p} 11)[8]$ \\
\hline & & & 4 & $46, \mathrm{XY}, \mathrm{t}(9 ; 22)(\mathrm{q} 34 ; \mathrm{q} 11), \operatorname{del}(15)(\mathrm{q} 22), \operatorname{add}(17)(\mathrm{p} 11)[7]$ \\
\hline & & & 7 & $46, \mathrm{XY}, \mathrm{t}(9 ; 22)(\mathrm{q} 34 ; \mathrm{q} 11), \operatorname{del}(15)(\mathrm{q} 22), \operatorname{add}(17)(\mathrm{p} 11)[10]$ \\
\hline & & & 10 & $46, \mathrm{XY}, \mathrm{t}(9 ; 22)(\mathrm{q} 34 ; \mathrm{q} 11), \operatorname{del}(15)(\mathrm{q} 22), \operatorname{add}(17)(\mathrm{p} 11)[7]$ \\
\hline 93 & M & 48 & 0 & $46, \mathrm{XY}, \mathrm{t}(4 ; 6)(\mathrm{q} 21 ; \mathrm{p} 23), \mathrm{t}(9 ; 22)(\mathrm{q} 34 ; \mathrm{q} 11)[20]$ \\
\hline 94 & M & 36 & 12 & $\begin{array}{l}46, \mathrm{XY}, \mathrm{t}(9 ; 22)(\mathrm{q} 34 ; \mathrm{q} 11)[8] / 46, \mathrm{XY}, \mathrm{t}(9 ; 22)(\mathrm{q} 34 ; \mathrm{q} 11), \mathrm{i}(9)(\mathrm{p} 10), \mathrm{der} \\
(17) \mathrm{t}(9 ; 17)(\mathrm{q} 11 ; \mathrm{p} 11)[12]\end{array}$ \\
\hline 95 & $\mathrm{~F}$ & 58 & 0 & $46, \mathrm{XX}, \mathrm{t}(9 ; 22)(\mathrm{q} 34 ; \mathrm{q} 11)[6] / 92, \mathrm{XXXX}, \mathrm{t}(9 ; 22)(\mathrm{q} 34 ; \mathrm{q} 11) \times 2[4]$ \\
\hline 96 & M & 44 & 0 & $46, \mathrm{XY}, \operatorname{der}(10), \mathrm{t}(9 ; 22)(\mathrm{q} 34 ; \mathrm{q} 11)[25]$ \\
\hline 97 & M & 46 & 0 & $46, \mathrm{XY}, \mathrm{t}(9 ; 22)(\mathrm{q} 34 ; \mathrm{q} 11), \mathrm{t}(14 ; 17)(\mathrm{p} 11 ; \mathrm{q} 11)[20]$ \\
\hline \multirow[t]{2}{*}{98} & M & 40 & 0 & $\begin{array}{l}46, \mathrm{XY}, \mathrm{t}(9 ; 22)(\mathrm{q} 34 ; \mathrm{q} 11)[2] / 46, \mathrm{XY}, \operatorname{del}(5)(\mathrm{q} 11 \mathrm{q} 14), \mathrm{t}(9 ; 22)(\mathrm{q} 34 ; \\
\mathrm{q} 11)[19]\end{array}$ \\
\hline & & & 6 & $46, \mathrm{XY}, \operatorname{del}(5)(\mathrm{q} 11 \mathrm{q} 14), \mathrm{t}(9 ; 22)(\mathrm{q} 34 ; \mathrm{q} 11)[2]$ \\
\hline
\end{tabular}




\begin{tabular}{|c|c|c|c|c|}
\hline 0. & Sex & $\mathrm{Age}^{\mathrm{a}}$ & Interval $^{\mathrm{b}}$ & Karyotype \\
\hline 99 & $\mathrm{~F}$ & 51 & 7 & $\begin{array}{l}\text { 46,XX,t(9;22)(q34;q11) [4]/45,XX, der(7;9)(q10;q10)t(9;22)(q34; } \\
\mathrm{q} 11), \operatorname{der}(22) \mathrm{t}(9 ; 22)(\mathrm{q} 34 ; \mathrm{q} 11)[8]\end{array}$ \\
\hline 100 & M & 27 & 0 & $46, \mathrm{XY}, \mathrm{t}(9 ; 22)(\mathrm{q} 34 ; \mathrm{q} 11)[20] / 45, \mathrm{XY}, \mathrm{t}(9 ; 22)(\mathrm{q} 34 ; \mathrm{q} 11),-21[4]$ \\
\hline 101 & $\mathrm{~F}$ & 52 & 0 & $46, \mathrm{XX}, \mathrm{t}(2 ; 16)(\mathrm{p} 2 ? 3 ; \mathrm{p} 1 ? 3), \mathrm{t}(9 ; 22)(\mathrm{q} 34 ; \mathrm{q} 11)[26]$ \\
\hline 102 & $\mathrm{~F}$ & 61 & 0 & $\begin{array}{l}46, \mathrm{XX}, \mathrm{t}(9 ; 22)(\mathrm{q} 34 ; \mathrm{q} 11)[21] / 46, \mathrm{XX}, \operatorname{del}(6)(\mathrm{q} 15 \mathrm{q} 23), \mathrm{t}(9 ; 22)(\mathrm{q} 34 ; \\
\mathrm{q} 11)[4]\end{array}$ \\
\hline 103 & $\mathrm{~F}$ & 68 & 0 & $\begin{array}{l}46, \mathrm{XX}, \mathrm{t}(9 ; 22)(\mathrm{q} 34 ; \mathrm{q} 11) / 46, \mathrm{XX}, \operatorname{del}(5)(\mathrm{q} 13 \mathrm{q} 22), \mathrm{t}(9 ; 22)(\mathrm{q} 34 ; \mathrm{q} 11) \\
{[24]}\end{array}$ \\
\hline 104 & $\mathrm{~F}$ & 64 & 0 & $46, \mathrm{XX}, \mathrm{t}(5 ; 8)(\mathrm{q} 14 ; \mathrm{q} 23), \mathrm{t}(9 ; 22)(\mathrm{q} 34 ; \mathrm{q} 11)[19]$ \\
\hline 105 & M & 37 & 0 & $46, \mathrm{XY}, \mathrm{t}(9 ; 22)(\mathrm{q} 34 ; \mathrm{q} 11), \mathrm{t}(15 ; 20)(\mathrm{q} 13 ; \mathrm{p} 12)[20]$ \\
\hline 106 & $\mathrm{~F}$ & 45 & 39 & $\begin{array}{l}46, \mathrm{XX}, \mathrm{t}(9 ; 22)(\mathrm{q} 34 ; \mathrm{q} 11.2)[16] / 46, \mathrm{XX}, \mathrm{t}(9 ; 22)(\mathrm{q} 34 ; \mathrm{q} 11.2), \operatorname{add}(20) \\
(\mathrm{p} 11.2)[9]\end{array}$ \\
\hline 107 & M & 19 & 0 & $\begin{array}{l}\text { 46,XY, } \operatorname{der}(1) \mathrm{t}(1 ; 9)(\mathrm{q} 21 ; \mathrm{q} 34) \mathrm{t}(9 ; 22)(\mathrm{q} 34: \mathrm{q} 11), \operatorname{der}(9) \mathrm{t}(1 ; 9)(\mathrm{q} 21 ; \\
\mathrm{q} 34) \mathrm{t}(9 ; 22)(\mathrm{q} 34: \mathrm{q} 11), \operatorname{der}(22) \mathrm{t}(9 ; 22)(\mathrm{q} 34 ; \mathrm{q} 11)[3]\end{array}$ \\
\hline 108 & $\mathrm{~F}$ & 65 & 86 & $\begin{array}{l}46, \mathrm{XX}, \mathrm{t}(9 ; 22)(\mathrm{q} 34 ; \mathrm{q} 11)[17] / 46, \mathrm{XX}, \operatorname{del}(\mathrm{X})(\mathrm{p} ? 21), \mathrm{t}(9 ; 22)(\mathrm{q} 34 ; \mathrm{q} 11) \\
{[6]}\end{array}$ \\
\hline \multirow[t]{2}{*}{109} & M & 64 & 10 & $46, \mathrm{XY}, \operatorname{add}(9)(\mathrm{q} 34), \operatorname{add}(9)(\mathrm{q} 32-34), \operatorname{der}(22) \mathrm{t}(9 ; 22)(\mathrm{q} 34 ; \mathrm{q} 11)[10]$ \\
\hline & & & 14 & $\begin{array}{l}\text { 46,XY,t(1;3)(p36;q2?6),add(9)(q34),add(9)(q32-34),der(22)t } \\
(9 ; 22)(\mathrm{q} 34 ; \mathrm{q} 11)[10]\end{array}$ \\
\hline \multirow[t]{3}{*}{110} & $\mathrm{~F}$ & 56 & 0 & $46, \mathrm{XX}, \mathrm{t}(1 ; 21)(\mathrm{q} 21 ; \mathrm{q} 22), \mathrm{t}(9 ; 22)(\mathrm{q} 34 ; \mathrm{q} 11)[20]$ \\
\hline & & & 12 & $46, \mathrm{XX}, \mathrm{t}(1 ; 21)(\mathrm{q} 21 ; \mathrm{q} 22), \mathrm{t}(9 ; 22)(\mathrm{q} 34 ; \mathrm{q} 11)[15]$ \\
\hline & & & 24 & $46, \mathrm{XX}, \mathrm{t}(1 ; 21)(\mathrm{q} 21 ; \mathrm{q} 22), \mathrm{t}(9 ; 22)(\mathrm{q} 34 ; \mathrm{q} 11)[2]$ \\
\hline 111 & M & 36 & 0 & $46, \mathrm{XY}, \mathrm{t}(9 ; 22)(\mathrm{q} 34 ; \mathrm{q} 11), \mathrm{t}(11 ; 19)(\mathrm{q} 14.1 ; \mathrm{q} 13)[20]$ \\
\hline 112 & M & 62 & 0 & $\begin{array}{l}\text { 46,XY,t( }(9 ; 22)(\mathrm{q} 34 ; \mathrm{q} 11)[2] / 46, \text { idem,add(8)(q24) [2]/45,idem,der } \\
(18) \mathrm{t}(10 ; 18)(\mathrm{q} 11 ; \mathrm{p} 11)[10]\end{array}$ \\
\hline 113 & M & 61 & 0 & $46, \mathrm{XY}, \mathrm{t}(1 ; 9)(\mathrm{q} 24 ; \mathrm{q} 31), \mathrm{t}(9 ; 22)(\mathrm{q} 34 ; \mathrm{q} 11)[20]$ \\
\hline 114 & $\mathrm{~F}$ & 46 & 0 & $46, \mathrm{XX}, \operatorname{der}(2) \mathrm{t}(2 ; 4)(\mathrm{q} 37 ; \mathrm{q} 21) \operatorname{del}(4)(\mathrm{q} 21), \mathrm{t}(9 ; 22)(\mathrm{q} 34 ; \mathrm{q} 11)[20]$ \\
\hline \multirow[t]{3}{*}{115} & M & 70 & 0 & $46, \mathrm{XY}, \operatorname{der}(9) \mathrm{t}(9 ; 22)(\mathrm{q} 34 ; \mathrm{q} 11), \mathrm{t}(10 ; 22)(\mathrm{q} 25 ; \mathrm{q} 13)[17]$ \\
\hline & & & 4 & $46, \mathrm{XY}, \operatorname{der}(9) \mathrm{t}(9 ; 22)(\mathrm{q} 34 ; \mathrm{q} 11), \mathrm{t}(10 ; 22)(\mathrm{q} 25 ; \mathrm{q} 13)[3]$ \\
\hline & & & 7 & $45, \mathrm{X},-\mathrm{Y}[3] / 46, \mathrm{XY}, \operatorname{der}(9) \mathrm{t}(9 ; 22)(\mathrm{q} 34 ; \mathrm{q} 11), \mathrm{t}(10 ; 22)(\mathrm{q} 25 ; \mathrm{q} 13)[2]$ \\
\hline 116 & $\mathrm{~F}$ & 69 & 94 & $46, \mathrm{XX}, \mathrm{t}(9 ; 22)(\mathrm{q} 34 ; \mathrm{q} 11), ? \operatorname{del}(17)(\mathrm{p} 12)[4]$ \\
\hline 117 & $\mathrm{~F}$ & 49 & 0 & $\begin{array}{l}\text { 46,XX,del(3)(p11p2?1)or(p21),t(9;22)(q34;q11) [12]/46,XX,del(3) } \\
\text { (p11p2?1)or(p21),del(5)(q15q31),t(9;22)(q34;q11)/46,XX,t(9;22) } \\
\text { (q34;q11) [2] }\end{array}$ \\
\hline \multirow[t]{2}{*}{118} & $\mathrm{~F}$ & 76 & 0 & $\begin{array}{l}46, \mathrm{XX}, \mathrm{t}(9 ; 22)(\mathrm{q} 34 ; \mathrm{q} 11)[7] / 46, \mathrm{XX}, \mathrm{t}(9 ; 22)(\mathrm{q} 34 ; \mathrm{q} 11), \operatorname{der}(19) \mathrm{t}(19 ; ?) \\
(\mathrm{p} 13.3 ; ?)[13]\end{array}$ \\
\hline & & & 4 & $\begin{array}{l}46, \mathrm{XX}, \mathrm{t}(9 ; 22)(\mathrm{q} 34 ; \mathrm{q} 11)[7] / 46, \mathrm{XX}, \mathrm{t}(9 ; 22)(\mathrm{q} 34 ; \mathrm{q} 11), \operatorname{der}(19) \mathrm{t} \\
(17 ; 19)(\mathrm{q} 22 ; \mathrm{p} 13)[13]\end{array}$ \\
\hline 119 & $\mathrm{M}$ & 40 & 3 & $46, \mathrm{XY}, \mathrm{t}(6 ; 15), \mathrm{t}(9 ; 22)(\mathrm{q} 34 ; \mathrm{q} 11)[6]$ \\
\hline 120 & M & 66 & 11 & $\begin{array}{l}46, \mathrm{XY}, \mathrm{t}(9 ; 22)(\mathrm{q} 34 ; \mathrm{q} 11)[9] / 46, \mathrm{XY}, \operatorname{der}(6) \mathrm{t}(6 ; 17)(\mathrm{p} 21 ; \mathrm{q} 11), \mathrm{t}(9 ; 22) \\
(\mathrm{q} 34 ; \mathrm{q} 11)[11]\end{array}$ \\
\hline \multirow[t]{2}{*}{121} & $\mathrm{~F}$ & 43 & 0 & $46, \mathrm{XX}, \mathrm{t}(7 ; 7)(\mathrm{p} 22 ; \mathrm{q} 22), \mathrm{t}(9 ; 22 ; 9)(\mathrm{q} 34 ; \mathrm{q} 11 ; \mathrm{p} 24)[16]$ \\
\hline & & & 60 & $40-43, \mathrm{XX}, \mathrm{t}(7 ; 7)(\mathrm{p} 22 ; \mathrm{q} 22), \mathrm{t}(9 ; 22 ; 9)(\mathrm{q} 34 ; \mathrm{q} 11 ; \mathrm{p} 24)$, inc $[\mathrm{cp} 3]$ \\
\hline 122 & M & 24 & 6 & $46, \mathrm{XY}, \mathrm{t}(2 ; 12)(\mathrm{q} 33 ; \mathrm{p} 13), \mathrm{t}(9 ; 22)(\mathrm{q} 34 ; \mathrm{q} 11)[20]$ \\
\hline \multirow[t]{2}{*}{123} & $\mathrm{~F}$ & 31 & 11 & $\begin{array}{l}\text { 46,XX,t(9;22)(q34;q11) [18]/ 46,XX,t(9;22)(q34;q11),ins(11;11) } \\
(\mathrm{p} 15 ; \mathrm{p} 11.2 \mathrm{p} 13)[4]\end{array}$ \\
\hline & & & 25 & $\begin{array}{l}\text { 46,XX,t(9;22)(q34;q11) [9]/ 46,XX,t(9;22)(q34;q11),ins(11;11) } \\
(\mathrm{p} 15 ; \mathrm{p} 11.2 \mathrm{p} 13)[5]\end{array}$ \\
\hline
\end{tabular}

${ }^{\mathrm{a} A g e}$ at diagnosis (years).

${ }^{\mathrm{b}}$ Interval between diagnosis and emergence of ACA (months).

\section{References}

1. Johansson B, Fioretos T, Mitelman F. Cytogenetic and molecular genetic evolution of chronic myeloid leukemia. Acta Haematol. 2002;107:76-94.

2. Mitelman F, Levan G, Nilsson PG, Brandt L. Non-random karyotypic evolution in chronic myeloid leukemia. Int $\mathrm{J}$ Cancer. 1976;18:24-30.

3. Sadamori N, Matsunaga M, Yao E, Ichimaru M, Sandberg AA. Chromosomal characteristics of chronic and blastic phases of Phpositive chronic myeloid leukemia. Cancer Genet Cytogenet. 1985;15:17-24.

4. Anastasi J, Feng J, Le Beau MM, Larson RA, Rowley JD, Vardiman JW. The relationship between secondary chromosomal abnormalities and blast transformation in chronic myelogenous leukemia. Leukemia. 1995;9:628-33.
5. Majlis A, Smith TL, Talpaz M, O'Brien S, Rios MB, Kantarjian HM. Significance of cytogenetic clonal evolution in chronic myelogenous leukemia. J Clin Oncol. 1996;14:196-203.

6. Marktel S, Marin D, Foot N, Szydlo R, Bua M, Karadimitris A, et al. Chronic myeloid leukemia in chronic phase responding to imatinib: the occurrence of additional cytogenetic abnormalities predicts disease progression. Haematologica. 2003; 88:260-7.

7. Cortes JE, Talpaz M, Giles F, O'Brien S, Rios MB, Shan J, et al. Prognostic significance of cytogenetic clonal evolution in patients with chronic myelogenous leukemia on imatinib mesylate therapy. Blood. 2003;101:3794-800.

8. Spiers ASD. Metamorphosis of chronic granulocytic leukemia: diagnosis, classification and management. Brit J Haematol. 1979;41:1-7.

9. Hehlmann R. How I treat CML blast crisis. Blood. 2012;120: $737-47$.

10. Cortes JE, Talpaz M, O'Brien S, Faderl S, Garcia-Manero G, Ferrajoli A, et al. Staging of chronic myeloid leukemia in the imatinib era: an evaluation of the World Health Organization proposal. Cancer. 2006;106:1306-15.

11. Hehlmann R, Hochhaus A, Baccarani M. Chronic myeloid leukemia. The Lancet. 2007;370:342-50.

12. Saußele S, Lauseker M, Gratwohl A, Beelen DW, Bunjes D, Schwerdtfeger R, et al. Allogeneic hematopoietic stem cell transplantation (alloSCT) for chronic myeloid leukemia in the imatinib era: evaluation of its impact within a subgroup of the randomized German CML Sudy IV. Blood. 2010;115:1880-5.

13. Gratwohl A, Pfirrmann M, Zander A, Kröger N, Beelen D, Novotny $\mathrm{J}$, et al. Long-term outcome of patients with newly diagnosed chronic myeloid leukemia: a randomized comparison of stem cell transplantation with drug treatment. Leukemia. 2016;30:562-9.

14. Perrotti D, Jamieson C, Goldman J, Skorski T. Chronic myeloid leukemia: mechanisms of blastic transformation. J Clin Invest. 2010;120:2254-64.

15. Koptyra M, Falinski R, Nowicki MO, Stoklosa T, Majsterek I, Nieborowska-Skorska M, et al. BCR/ABL kinase induces selfmutagenesis via reactive oxygen species to encode imatinib resistance. Blood. 2006;108:319-27.

16. Fabarius A, Leitner A, Hochhaus A, Müller MC, Hanfstein B, Haferlach C, et al. Impact of additional cytogenetic aberrations at diagnosis on prognosis of CML: long-term observation of 1151 patients from the randomized CML Study IV. Blood. 2011;118:6760-8.

17. Wang W, Cortes JE, Tang G, Khoury JD, Wang S, Bueso-Ramos $\mathrm{CE}$, et al. Risk stratification of chromosomal abnormalities in chronic myelogenous leukemia in the era of tyrosine kinase inhibitor therapy. Blood. 2016;127:2742-50.

18. Wang W, Cortes JE, Lin P, Beaty MW, Ai D, Amin HM, et al. Clinical and prognostic significance of 3q26.2 and other chromosome 3 abnormalities in CML in the era of tyrosine kinase inhibitors. Blood. 2015a;126:1699-706.

19. Wang W, Tang G, Cortes JE, Liu H, Ai D, Yin CC, et al. Chromosomal rearrangement involving 11q23 locus in chronic myelogenous leukemia: a rare phenomenon frequently associated with disease progression and poor prognosis. Journal of hematology \& oncology. 2015b;8:32.

20. Wang W, Cortes JE, Lin P, Khoury JD, Ai D, Tang Z, et al. Impact of trisomy 8 on treatment response and survival of patients with CML in the era of tyrosine kinase inhibitors. Leukemia. 2015c;29:2263-6.

21. Gong Z, Medeiros LJ, Cortes JE, Chen Z, Zheng L, Li Y, et al. Cytogenetics-based risk prediction of blastic transformation of chronic myeloid leukemia in the era of TKI therapy. Blood Adv. 2017;1:2541-52. 
22. Hehlmann R. Prognostic relevance of CCAs/Ph- in CML settled. Blood. 2017;130:2046-7.

23. Issa GC, Kantarjian H, Nogueras Gonzalez G, Borthakur G, Tang $\mathrm{G}$, Wierda W, et al. Clonal chromosomal abnormalities appearing in Philadelphia chromosome-negative metaphases during CML treatment. Blood. 2017;130:2084-91.

24. Hehlmann R, Lauseker M, Saußele S, Pfirrmann M, Krause S, Kolb HJ, et al. Assessment of imatinib as first-line treatment of chronic myeloid leukemia: 10-year survival results of the randomized CML study IV and impact of non-CML determinants. Leukemia. 2017;31:2398-406.

25. Pfirrmann M, Baccarani M, Saussele S, Guilhot J, Cervantes F, Ossenkoppele G, et al. Prognosis of long-term survival considering disease-specific death in patients with chronic myeloid leukemia. Leukemia. 2016;30:48-56.

26. Fabarius A, Kalmanti L, Dietz CT, Lauseker M, Rinaldetti S, Haferlach $\mathrm{C}$, et al. Impact of unbalanced minor route versus major route karyotypes at diagnosis on prognosis of CML. Ann Hematol. 2015;94:2015-24.

27. Hehlmann R, Müller MC, Lauseker M, Hanfstein B, Fabarius A, Schreiber A, et al. Deep molecular response is reached by the majority of patients treated with imatinib, predicts survival, and is achieved more quickly by optimized high-dose imatinib: results from the randomized CML-study IV. J Clin Oncol. 2014;32:415-23.

28. Cross NCP, White HE, Müller MC, Saglio G, Hochhaus A. Standardized definitions of molecular response in chronic myeloid leukemia. Leukemia. 2012;26:2172-5.

29. Cross NC, Hochhaus A, Müller MC. Molecular monitoring of chronic myeloid leukemia: principles and interlaboratory standardization. Ann Hematol. 2015;94(Suppl 2):S219-25.
30. Cross NC, White HE, Colomer D, Ehrencrona H, Foroni L, Gottardi E, et al. Laboratory recommendations for scoring deep molecular responses following treatment for chronic myeloid leukemia. Leukemia. 2015;29:999-1003.

31. Baccarani M, Deininger MW, Rosti G, Hochhaus A, Soverini S, Apperley JF, et al. European LeukemiaNet recommendations for the management of chronic myeloid leukemia: 2013. Blood. 2013;122:872-84.

32. Arber DA, Orazi A, Hasserjian R, Thiele J, Borowitz MJ, Le Beau $\mathrm{MM}$, et al. The 2016 revision of the WHO classification of myeloid neoplasms and acute leukemia. Blood. 2016; 127:2391-405.

33. Rea D, Etienne G, Nicolini F, Cony-Makhoul P, Johnson-Ansah $\mathrm{H}$, Legros L, et al. First-line imatinib mesylate in patients with newly diagnosed accelerated phase-chronic myeloid leukemia. Leukemia. 2012;26:2254-9.

34. Branford S, Wang P, Yeung DT, Thomsen D, Purins A, Wadham $\mathrm{C}$, et al. Integrative genomic analysis reveals cancer-associated mutations at diagnosis of CML in patients with high-risk disease. Blood. 2018;132:948-61.

35. Boullion A-S, Ventura Ferreira MS, Adnan Awad S, Richter J, Hochhaus A, Kunzmann V, et al. Telomere shortening correlates with leukemic stem cell burden at diagnosis of chronic myeloid leukemia. Blood Adv. 2018;2:1572-9.

36. Haaß W, Kleiner H, Weiß C, Haferlach C, Schlegelberger B, Müller MC, et al. Clonal evolution and blast crisis correlate with enhanced proteolytic activity of separase in BCR-ABL b3a2 fusion type CML under imatinib therapy. PLoS ONE. 2015. https://doi.org/10.1371/journal.pone.0129648:1-18. 